incisors in these Marsupials ; nor does it even express either so definitely or clearly some of the peculiarities of the movement as observations which we have quoted at length.

\title{
January $23,1866$.
}

Dr. J. E. Gray, F.R.S., V.P., in the Chair.

Mr. P. L. Sclater exhibited an egg of the One-carunculated Cassowaiy (Casuarius uniappendiculatus, Blyth), laid by the female bird in the Zoological Gardens, Amsterdam. The egg was of the usual form and colour of the eggs of the genus Casuarius, being of a pale green, thickly covered with raised spots of dark green, and measuring 5.4 by 3.6 inches.

$\mathrm{Mr}$. Sclater called the attention of the Society to the great scarcity in European collections of specimens of the American Lepidosiren (Lepidosiren paradoxa). But two examples of this creature had been obtained by Natterer, its original discoverer,- - one from a waterditch near Borba on the Madeira, where it appeared to be known to the inhabitants by the name "Caramuru;" the other in a marsh on the right bank of the Amazons, above Villa Nova. These specimens were now in the Imperial Zoological Cabinet at Vienna.

The only other travellers who appeared to have met with this singular form were MM. Castelnau and Deville, who obtained a single specimen of a Lepidosiren from a lake on the Ucayali, which M. de Castelnau, in the volume devoted to the fishes collected by his expedition, has referred to a second species of the genus, under the name L. dissimilis.

Neither Mr. Wallace nor Mr. Bates had obtained specimens of this animal during their Amazonian wanderings. Mr. Wallace had only heard of it. Mr. Bates had replied as follows in answer to $\mathrm{Mr}$. Sclater's inquiries on the subject:-

"What I have to tell you about the Lepidosiren of the Amazons is very little. Judging from my experience (having made constant inquiries about it during the three years I was living in the proper localities, without obtaining a specimen), it is not easy to get; but another traveller, having means of obtaining a good boat's crew during the dry months (which I had not), might be more successful. I exhibited drawings to many native fishermen, and they recognized the Lepidosiren as a fish they occasionally find in the mud at the bottom of the great lakes when they spend the dry seasons in harpooning and salting Pirarecú (Sudis gigas). They call it in the Tupi language 'Tambaki-mboya,' i. e. Tambaki (a very common eatable fish, of the family Characini), mboya, false, it being scaled similarly to the 


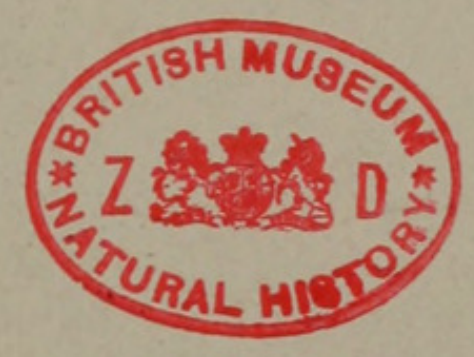




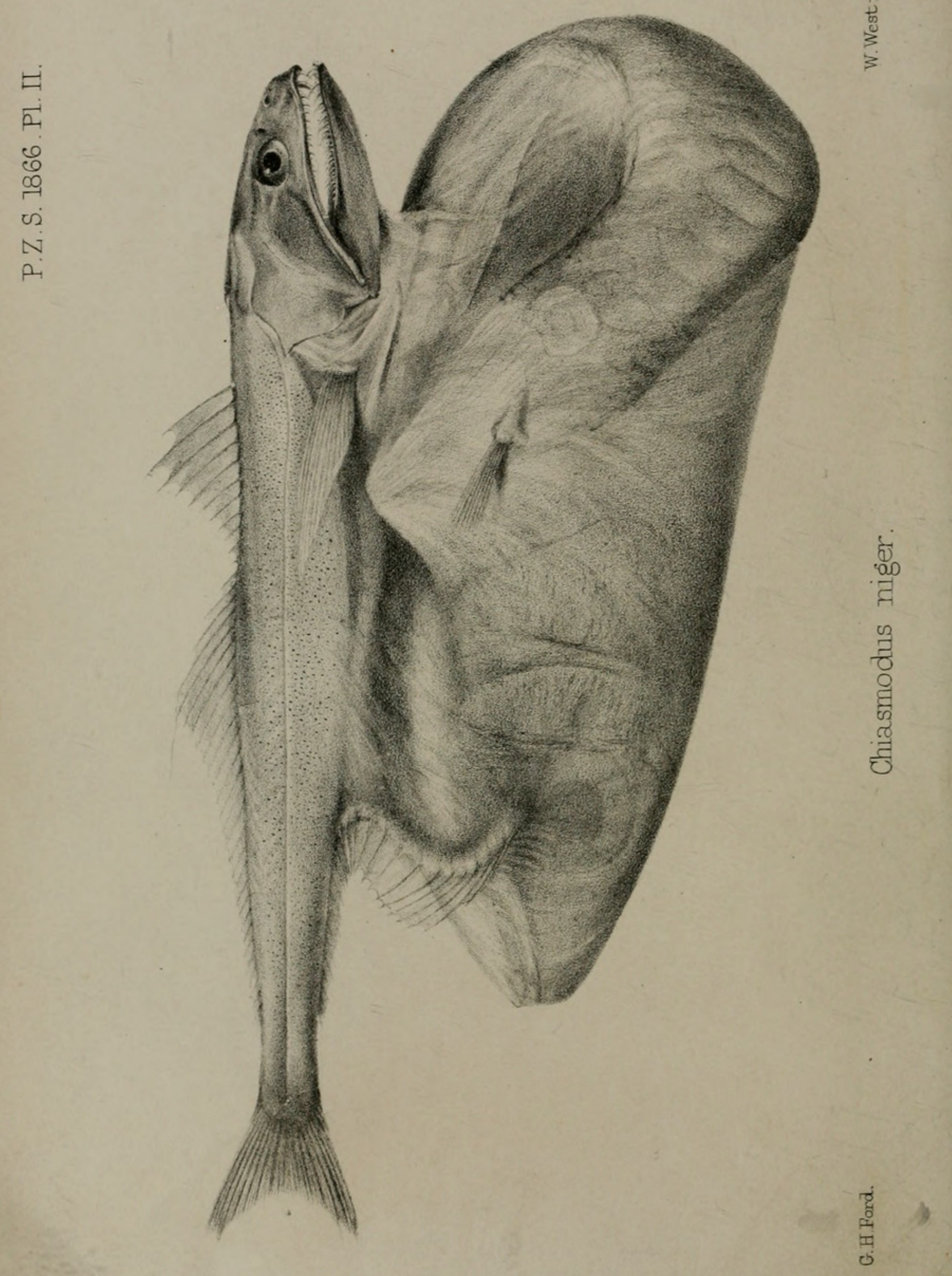


Tambaki, and yet not having the necessary character of a fish, in fins being absent.

"In the Upper Amazons, where I had a boat of my own and spent weeks on the lakes and still waters in the dry season, I could not get any information about the 'Tambaki-mboya.' It seems therefore to be confined to the great lakes about the Tapajos and the Madeira rivers. If hands are so scarce in that part as they were in my time, I do not know how a foreigner is to obtain a boat's crew to go in search of it."

Dr. J. Murie read some notes on the Markhore (Capra megaceros), chiefly based upon a specimen of this animal which had recently died in the Society's Gardens. Dr. Murie also gave some account of the morbid appearances he had observed in a Chimpanzee which had lately died in the Menagerie.

The following papers were read :-

1. Notes on the Genus Chiasmodon. By Alexander Carte, M.D., M.A. Univ. Dub., M.R.I.A., F.L.S., \&c.

(Plate II.)

In the month of August 1865 I received from Commodore Sir Leopold MrClintock, R.N., a specimen of a fish which had been taken near the Island of Dominica, about which he writes :-

"Dr. Imray, of Castries, Dominica, has given me a specimen of which the two sketches enclosed may afford you some idea. A small fish with teeth inclined backwards swallowed a much larger one, and whilst helplessly floating was picked up and given to Dr. Imray. The swallowed fish was dead, the swallower still alive; the abdominal integument of the latter has been stretched enormously, and is as thin and transparent as goldbeaters' leaf, but quite perfect. Both fishes are known out here; but the smaller one is much the more rare."

On examination there could be no doubt that the smaller specimen was referable to the genus Chiasmodon of Mr. Johnson*, which has since been placed by Dr. Günther among the Gadida.

The specimens in the British Museum would indicate a species of rather diminutive size, one of them measuring only $2 \frac{3}{4}$ and the other $3 \frac{1}{2}$ inches in length; whereas the specimen obtained by Dr. Imray measures nearly twice the length of the longer of these. There is also a difference in the colour of the skin: Mr. Johnson states his to be black, while Dr. Imray's is dark brown; otherwise it might be referred to the same species.

The following is a detailed description of the specimen, with the measurements :-

The body is of a dark-brown colour along its dorsal aspect; produced by numerous minute circular brown dots (pigment-cells) stip-

* Vide Proc. Zool. Soc. 1863, p. 408. 
pled over the surface, those in the situation of the pectoral fins being the largest; this colour gradually changes to a yellowish tinge on the sides in the region of the lateral line. The body is elongated, slender, and compressed on the sides ; head unarmed, laterally compressed, with a shallow but rather wide groove extending between the orbits, bounded by two somewhat bluntish ridges, which meet in front at a point immediately above and between the anterior nostrils; cheeks flattish; operculum somewhat triangular or arrow-shaped in outline, with an excavation in its upper and a deep notch in its inferior border, the latter being situated between the sub- and interopercula.

The orbits lateral, longitudinally oval in shape, and distant about a diameter and a half from the truncated muzzle, with their posterior borders corresponding to the central point of the superior maxilla.

The anterior pair of nostrils are round and appear the larger, they are situated about midway between the muzzle and the anterior edge of the orbit; the posterior pair are somewhat triangular, and are placed close to the anterior superior border of the orbit. The head is studded with numerous mucous pores. The muzzle is truncated in front and submarginate, the inferior maxilla extending slightly beyond it. The cleft of the mouth is slightly arched, and long, extending backwards far behind the orbits, the slender and emarginate premaxillaries forming the entire of its upper border.

In each maxilla there are two rows of irregularly placed subulate teeth, the inner row being the larger, but containing fewer teeth. They are arranged as follows :-In the superior maxilla, commencing at the muzzle, there are two long immoveable hooked teeth, with their points directed inwards towards each other, so as almost to meet; at the base and external side of each of these, a minute sharp denticle is situated; immediately behind these, but in the inner row, there are two other large moveable hooked teeth, the points of which incline towards each other, but do not touch; these are the longest teeth in the upper jaw. The sixth tooth, counting backwards on either side from the two long immoveable front teeth, is also a long but moveable tooth, and is inserted on the inner aspect of the superior maxilla at a point a little posterior to the anterior margin of the orbit. The remainder of the teeth in this jaw are small, and gradually diminish in size as they approach the articulation; they are implanted irregularly in a double series.

The teeth in the inferior maxilla are thus arranged:-In front there are a pair of very minute denticles, immediately external to and at the bases of which are two long immoveable teeth with their points curved outwards; following these are two pairs of still longer moveable teeth, the posterior pair of which are the longest of the whole series. The remainder of the teeth in this jaw, like those in the upper, are small and are implanted irregularly in a double series as far back as the articulation. The palate is furnished with a series of small denticles, and there is a somewhat similar series placed along. the central line of the tongue; this latter organ is long and narrow, 
its tip is free and of a greyish-yellow colour. There appear to be no vomerine teeth, no barbel, nor pseudobranchiæ.

The pectoral fins, which contain twelve(?) very slender rays, are inserted immediately below the excavation in the posterior inferior margin of the operculum, its pointed extremity extending backwards for about $1 \frac{1}{8}$ inch.

The ventrals are so misplaced, in consequence of the great distension of the abdominal parietes of the fish, that it is impossible to give an accurate description of their normal position. In length they measure about nine-sixteenths of an inch, and contain about six delicate subequal rays.

The anal fin, from the same cause, is greatly displaced: instead of holding its normal position along the ventral surface of the fish, it is completely separated from it and carried down on the distended and greatly thinned abdominal integument; and the points of its rays are so mutilated that they cannot be measured with accuracy. The course of the intestine is distinctly visible through the semitransparent integument, running downwards and backwards to the anal orifice; both it and the anal orifice, as may be seen by reference to the accompanying figure (Plate II.), are also much displaced.

As, for obvious reasons, it was not considered advisable to dissect this curious and interesting specimen, I cannot add any further particulars, in reference to the rest of the alimentary system, to those which have already been recorded by Mr. Johnson.

The caudal fin is furcate, and contains about eleven principal rays, of which the longest measures about $1 \mathrm{inch}$. The lateral line runs for the greater part of its course straight along the centre of the body, but as it approaches the head it curves upwards behind the posterior superior margin of the operculum.

Total

Total length of specimen from snout to extremity of tail .. $6 \frac{5}{8}$

Total length of head from snout to point of operculum.... $1 \frac{5}{8}$

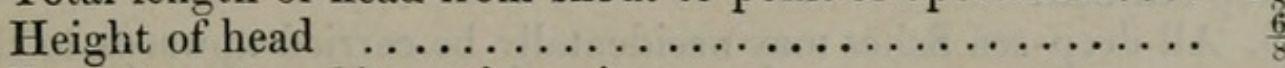

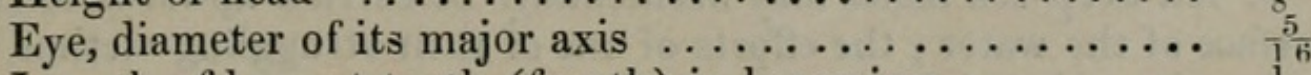

Length of longest tooth (fourth) in lower jaw . . . . . . .

Distance of first dorsal fin from muzzle, about ........ $1 \frac{3}{4}$

Length of pectorals........................ $1 \frac{1}{8}$

Width of the base of pectorals $\ldots \ldots \ldots \ldots \ldots \ldots \ldots \ldots, \quad \frac{1}{8}$

Distance of pectorals from muzzle $\ldots \ldots \ldots \ldots \ldots \ldots \ldots, 1 \frac{1}{2}$

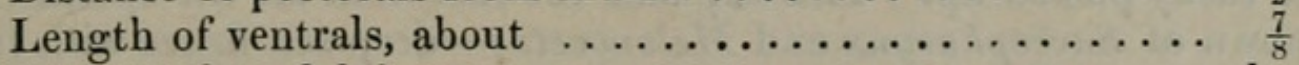

$\underline{1}$ of caudal fin ...................... 1

The length of the enclosed fish (Scopelus macrolepidotus?) . $10 \frac{1}{2}$

Depth at pectorals $\ldots \ldots \ldots \ldots \ldots \ldots \ldots \ldots \ldots \ldots \ldots \ldots \ldots \ldots \ldots \ldots \ldots$

In a subsequent letter received from Sir Leopold $\mathbf{M}^{\mathrm{c}}$ Clintock, dated from Port Royal, Jamaica, the 6th of November, 1865, he says, "They are not deep-water fish; both are well known at Dominica, more particularly the larger one (S. macrolepidotus?), which is common. The smaller one ( $\boldsymbol{C}$. niger ?) is not common; but the 
natives have names for both of them, so that neither of them can be considered rare."

It may be expected, before concluding these notes, that some theory or explanation should be offered on the interesting problem of how the larger fish (S. macrolepidotus?) became enclosed in the interior of the smaller (C. niger?); but I am disposed to think it more judicious, until further information on the habits and anatomy of the latter is obtained, to leave this an open question.

I believe that prior to this there have been but two other, and much smaller, specimens obtained, by Mr. Johnson and the Rev. R. T. Lowe at Madeira; and they are described as taken at a depth of from 200 to 300 fathoms, whereas it will be seen by Sir L. $M^{\mathrm{e}}$ Clintock's letter that he does not consider the present specimen a deep-water fish, nor does he consider it to be so rare, at least near the island of Dominica, as Mr. Johnson found his specimens to be at Madeira. I trust that further specimens, which I expect to receive through the aid of Sir Leopold $\mathrm{M}^{\mathrm{c}}$ Clintock, will satisfactorily determine both these problems.

Dr. Günther added the following remarks to this paper:-

1. The fish described is undoubtedly identical with Chiasmodus niger, Johnson, as I had supposed at once when the figure was shown to me.

2. The fish swallowed is most probably Scopelus macrolepidotus, Johnson; but as it is still enveloped in the membranes of the stomach of the swallower and doubled up, some doubt as regards its identification may be entertained.

3. The specimen examined by Mr. Johnson was obtained under similar circumstances as that received from Dominica; it had in its stomach another, pelagic fish, nearly twice its own length.

4. The specimen obtained by the Rev. R. T. Lowe was taken at a depth of 312 fathoms, which is sufficient proof that the species is a deep-sea fish.

5. All deep-sea fishes may aecidentally be carried upwards to the surface of the water ; the efforts of one of their struggling victims to escape from their jaws may cause them to ascend with it beyond the horizontal zone which they usually inhabit; and when once beyond it, and under a greatly diminished pressure, they become as helpless as a man who ascends to a great height in a balloon, and therefore are easily picked up. This explains the fact that all the specimens known of Saccopharynx and Melanocetus-deep-sea fishes with the same extensible stomach as Chiasmodus-were found with large fishes in their stomachs. The specimens swallowed were found in each case to be in a very early state of digestion; and one was so well preserved that it was recognized and described as the type of a new genus.

6. The circumstance that the fishermen of Dominica have names for the two fishes does not prove their common occurrence. All our rarest British fish, like the "King of the Herrings," \&c., have names. However, from what Sir L. Mic Clintock says, both these extraordi- 


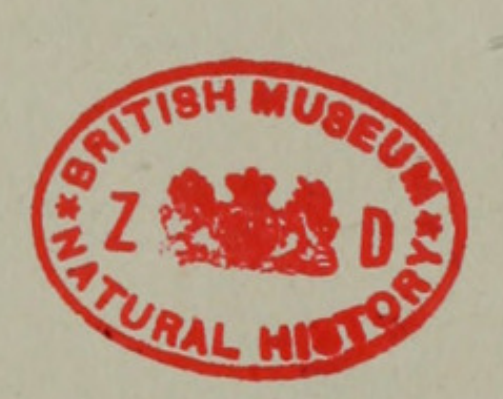




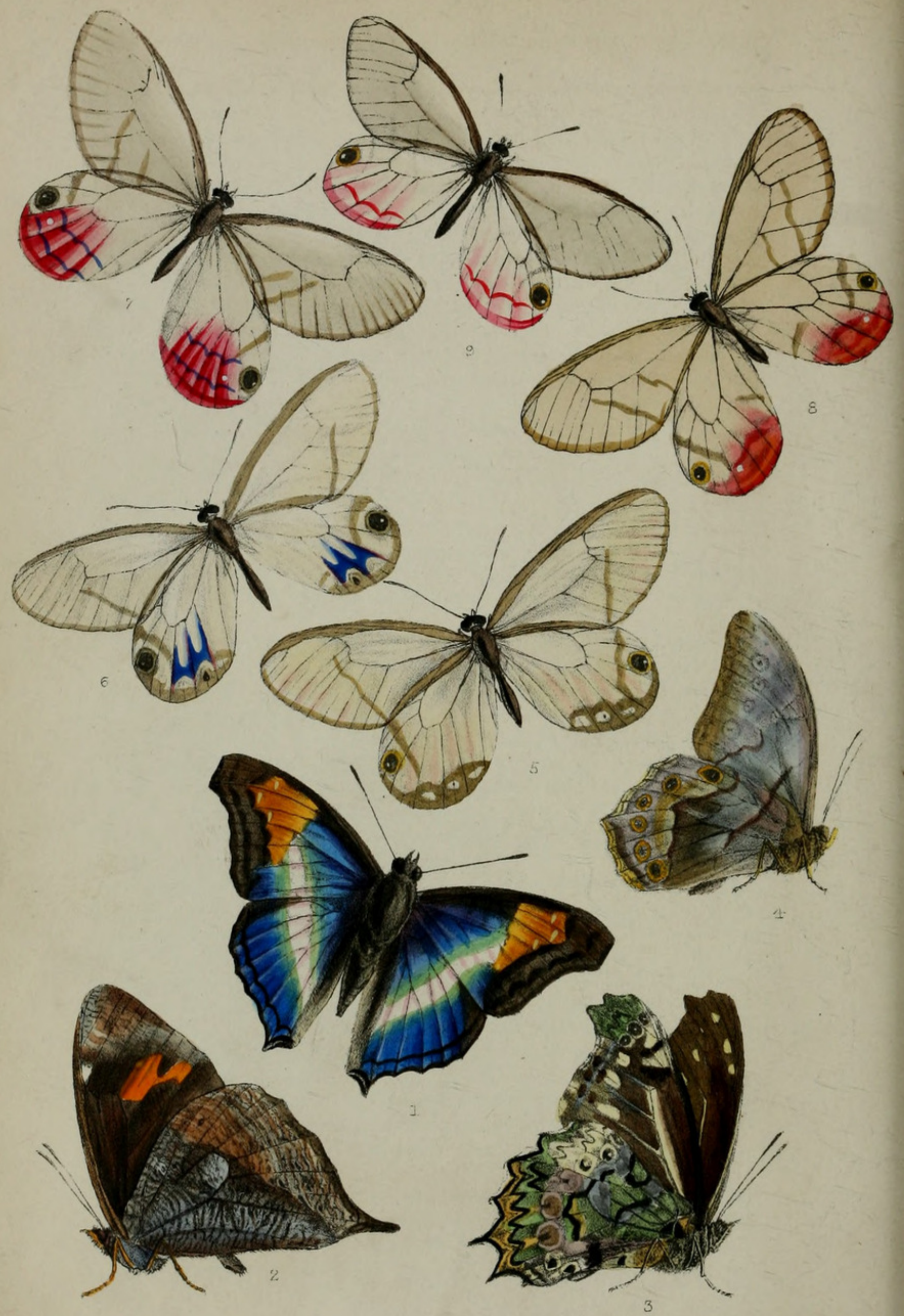


nary species must be more common in the West Indies than in the sea off Madeira.

7. The process of deglutition in all these fishes is evidently very simple. The fish, after having seized its victim with its sufficiently capacious and very moveable jaws, partly presses it down, as a snake would do, partly draws itself over it. The prey is received into an œsophagus and stomach the membranes of which are, like the external integument, extensible as an India-rubber pouch, and which, therefore, may contain a body twice or thrice the size of the destroyer. Organs externally attached to the integument, like the ventral fins, are naturally displaced. I have seen the empty stomach of Chiasmodus, in the specimen obtained by Mr. Lowe; it was contracted, folded up, and but little projecting downwards from the belly.

2. Descriptions of some New Exotic Butterflies in the National Collection. By Arthur G. Butler, F.Z.S., Assistant, Zoological Department, British Museum.

\section{(Plate III.)}

1. Chlorippe (Apatura) lavinia ( $\delta^{\sigma}$ ), sp.n. (Pl. III. fig. 1.)

Upperside-front wings rich reddish brown, with a central band of white spots, the upper ones almost obscured by a large orange wedge-shaped patch, and surrounded, below this patch, by a band of bright metallic green; the centre of the wings also glossed with brilliant purplish blue; cell paler brown, crossed by two dark central bands; outer margin with two pale submarginal bands; cilia white. Hind wings rich reddish brown, with a central white band surrounded by a band of bright metallic green; the entire wing, except the margins, glossed with brilliant purplish blue; inner margin pale brown; two pale submarginal bands at the outer margin; a fine white lunule at the anal angle, and a greenish lunule a little above it; cilia white. Body rich brown; anal half of abdomen pale brown; palpi reddish.

Underside nearly the same as in C. lucasii, Westw., Doubl. \& Hewits. (Amazons, \&c.), but the front wing is more suffused with orange.

Expanse of wings $2 \frac{3}{8}$ inches.

Hab. Amazons (Nauta).

\section{$1^{a}$. Chlorippe lavinia ( $q$ ?).}

Upperside-basal half reddish brown; apical half orange-ochreous, in the front wings rather dusky; a central white band, iridescent in the hind wings; three submarginal dark brown bands; three triangularly placed subapical white spots in the front wings; inner margin of hind wings ochreous. Body brown; palpi ochreous ; antennæ reddish. 
Underside as in the male, except that the hind wings are coppercoloured and the central band is broader and more regular in outline. Body creamy white ; proboscis and prolegs yellow ; tibiæ of other legs and antennæ orange.

Expanse of wings $2 \frac{5}{8}$ inches.

Hab. Venezuela.

Allied to C.laurentia, Godart; but the male is very easily distinguished by the large orange patch in the front wings. The female may possibly not belong to this species; but it seems to me to be more nearly allied to it than to the other metallic insects in this genus.

\section{Corades cybele, sp. n. (Pl. III. fig. 2.)}

Upperside rich browu; antennæ reddish.

Underside-front wings rich brown; a dirty-white spot on the front margin beyond the cell; apex pale brown, mottled with reddish brown; a large orange blotch between the second and third median branches, and continued in the form of a lunule below to the first branch; a small red spot near the anal angle. Hind wings, basal half grey, apical half ochreous clouded with grey-brown; mottled with numerous small irregular red-brown spots and streaks, more plentifully towards the centre of the wing and the outer margin ; anal tail brown. Body grey; palpi, legs, and antennæ dull orange.

Hab. Bogota.

Allied to Corades sareba, Hewits. (from Bolivia), but very different.

\section{Dedalma emilia, sp. n. (Pl. III. fig. 3.)}

Upperside-front wings rich brown; front margin, median vein, cilia, and a submarginal elbowed row of nine spots yellow. Hind wings rich brown; cilia and two submarginal rows of spots yellow. Body brown; thorax with dark-greenish hairs; antennæ brown, reddish at the tips.

Underside-front wings rich reddish brown; apex varied with greenish and silvery brown; three subapical black spots pupillated with white, and two black subapical lunules; median nervure, four submarginal spots between the median nervules, a triangular spot on the front margin beyond the cell, and two marginal spots at the anal angle pale green. Hind wings, basal half olive-green, varied with silver patches partially edged with black; base reddish brown; apical half olive-green, varied with pale green and brown; a central band of eight ocelli, the two upper ones pale green with darker centres, the others pale brown with reddish-brown centres, and divided downwards from the centre by a black line ; all the ocelli pupillated with white; a very irregular wavy black submarginal line margined outwardly with pale green; outer margin black; cilia silver. Body grey brown; palpi and legs grey; antennæ grey, darker at the tips.

Expanse of wings $2 \frac{15}{16}$ inches.

Bogota. 
Allied to Dadalma dorate, Hewits., but very distinct, the hind wing being totally unlike in outline, the front wing above having only one row of spots ; below, the lower ocelli of the front wings are absent, and replaced by large greenish oblong spots ; the markings of the hind wings are also very dissimilar.

\section{Debis isabella ( $\sigma^{\circ}$ ), sp. n. (Pl. III. fig. 4.)}

Upperside rich brown; outer margin of hind wings ferruginous, anal portion submarginated with two black lunules; a submarginal row of six black spots, indistinct at the apex and anal angle. Body brown ; palpi ochreous; antennæ ferruginous, with orange tips.

Underside-front wings grey, glossed with violaceous; base, a transverse central band, and a triangular dash tapering from the costa near the apex deeper grey ; outer margin clouded with ochreous; a transverse brown line near the base; a very irregular more indistinct brown line beyond the end of the cell; outer margin with two marginal grey lines, wavy towards the apex ; a submarginal row of six pale grey ocelli, the uppermost one very indistinct. Hind wings grey, clouded with brown and ochreous; a broad irregular central band pale ochreous above, below grey inwardly, brown outwardly, margined by a rich-brown line on each side; a small brown dash at the end of the cell; outer margin with three marginal brown lines; a submarginal row of six large ocellate spots bright ochreous, with large black centres irrorated with silver. Body greyish ochreous.

Expanse of wing $2 \frac{5}{8}$ inches.

Hab. Philippine Islands.

Closely allied to Debis chandica ( $\left.\sigma^{*}\right)$, Moore (E. Indies); it differs from it as follows :-Front wings much more elongate; outer margin more distinctly emarginate, forming an angle at the fold between the second and third median branches. Hind wings more elongate; the central caudate projection more produced, the outer margin more deeply sinuated. On the upperside, hind wings, outer margin richly suffiused with reddish ferruginous, upon which the submarginal spots are distinctly visible; fringe of the wings dark ; antennæ ferruginous. On the underside, front wings, central line much more irregular and more indistinct; both the marginal lines of the outer margin waved near the apex. Hind wings, central band much more regular in outline, not so much produced at the centre of its lower edge, not so broad near the costa, but broader below the median nervure than in D. chandica ; submarginal ocelli smaller and further apart.

\section{Hetera pellucida, sp. n. (Pl. III. fig. 5.)}

\section{H. phelis, Boisd. MS.}

Upperside transparent, iridescent. Front wings with the margins, nervures, and an oblique streak at the anal angle brown. Hind wings with the marginal edges, nervures, outer margin, and a submarginal irregular band adjoining it brown; a large ocellus at the apex black, glossed with ultramarine blue, pupillated with white and encircled with orange; two small circular white spots near the hind margin 
between the nervures. Body, thorax, and antennæ pale reddish brown; abdomen dark brown.

Underside-wings as above. Body-thorax white; legs and abdomen ochreous; antennæ pale brown.

Expanse of wings $2 \frac{1}{2}$ inches.

Hab. Cayenne.

\section{Hetera harpalyce, sp. n.* (Pl. III. fig. 6.)}

Upperside-front wings as in the preceding species. Hind wings, lower half richly glossed with purple; a large ocellus as in $H$. pellucida; a similar smaller ocellus near the outer margin between the second and first median branches; two small circular white spots between the two ocelli; other markings as in $H$. pellucida.

Underside-front wings as above. Hind wings as above, but without the purple gloss. Body wanting, probably the same as in the preceding species.

Expanse of wings $2 \frac{1}{2}$ inches.

Hab. Upper Amazons?

This species is allied to H. esmeralda, Doubleday, but differs from it in the greater extent of the purple gloss in the hind wings, the unbroken submarginal band, an additional ocellus, and its greater size. It is also allied to $H$. philis, Cramer, wrongly placed as a synonym of $H$. aurora, Feld., under its old name of $H$. andromeda $\uparrow$.

The species figured by Cramer (iv. pl. 387, f. E) as H. philis is quite distinct from $H$. pireta, Cramer, pl. 315 . f. A ; it has a violet, not a carmine, suffusion on the hind wings; and the colouring in H. philis is confined to the centre of the disk, instead of covering nearly the whole of the lower portion of the wing.

If these differences existed merely in Cramer's figures, pls. 315 $\& 38 \mathrm{~T}$, they might be attributed to colour-blindness or carelessness ; but as the same differences are found in the descriptions (pireta"la tache rouge") (philis- " une tache luisante couleur de violet"), there can be no more doubt that the two insects are distinct.

Note.-It appears to me that the insect heretofore in our collections under the name of $\boldsymbol{H}$. andromeda (Pl. III. fig. 9), although not the species intended by Fabricius (Drury, iii. pl. 38. f. 3), should not be named in collections $H$. aurora, Felder (Pl. III. figs. 7, 8), although it may be identical with $H$. pireta, Cramer.

\section{DESCRIPTION OF PLATE III.}

Fig. 1. Apatura lavinia, p. 39.

2. Corades cybele, p. 40.

3. Dadalma emilia, p. 40.

4. Debis isabella, p. 41.
Fig. 5. Hetcra pellucida, p. 41.

6. - harpalyce, p. 42.

7, 8. - aurora, p. 42.

9. - andromeda, p. 42.

* Possibly the other sex of $H$. pellucida.

† Vide Bates on New Sp. Butterf. from Guatemala and Panama, Ent. Month. Mag. i. p. $180,1865$. 
6 


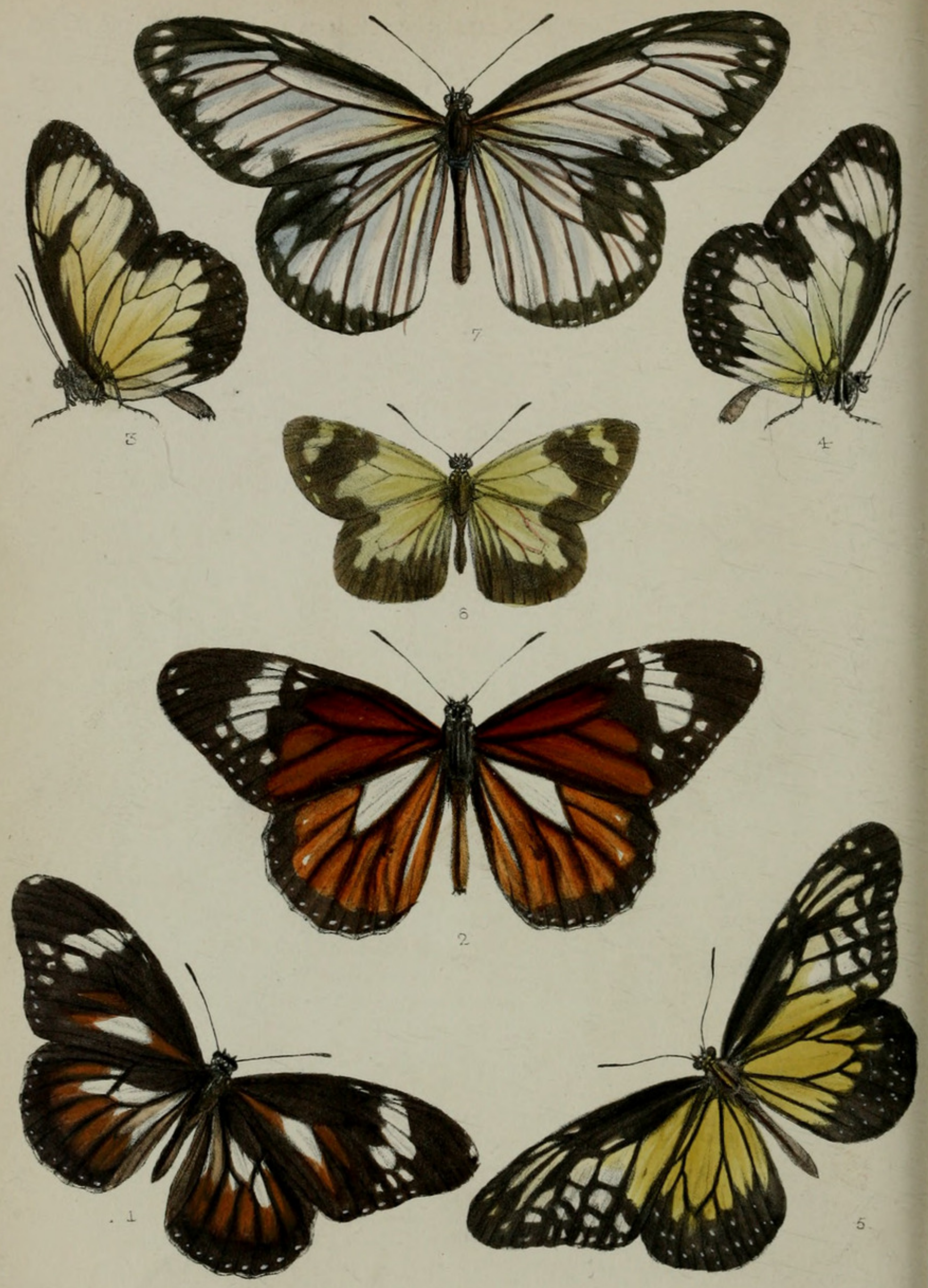


3. A Monograph of the Diurnal Lepidoptera belonging to the Genus Danais, being a Revision of the Insects of that Genus, with Descriptions of New Species in the National Collection. By Arthur G. Butler, F.Z.S., Assistant, Zoological Department, British Museum.

(Plate IV.)

Genus Danais, Latreille.

Danaida, Danaus, or Danais, Latreille (1805).

Danais, Godart, Enc. Méth. ix. (1819); Boisduval, E. Doubleday, List Lep. Brit. Mus. (1844); Westwood, Doubleday \& Hewitson, Gen. Diurn. Lepid. (1847); F. Moore, Cat. Lep. Mus. East India Comp. (1857); Trimen, Rhop. Afric. Austral. (1862).

Amauris, Hestia (part.), Euploa, Limnas, Anosia, Hübner, Verz. bek. Schmett. (1816).

Ideopsis (part.), Horsfield, Moore, Lep. Mus. E. I. C. (1857).

\section{Section 1.}

\section{Danais Phedon.}

Papilio phadon, Fabricius, Ent. Syst. Suppl. v. p. 423. nos. 184, 185 (1793).

Danais phadon, Godart, Enc. M. ix. p. 183. n. 26 (1819); Westw., Doubl. \& Hewits. Gen. Diurn. Lep. p. 91. n. 1 (1843).

Euploea phadon, Boisd. Faune Ent. de Madag. t. 3. f. 3 (1833). Hab. Mauritius.

B.M.

\section{Danais echeria.}

Papilio echeria, Stoll, t. 29. f. 1, 1 a (1790).

Amauris echeria, Hübner, Verz. bek. Schmett. p. 14 (1816).

Euplaa echeria, E. Doubl. List Lep. Brit. Mus. p. 49 (1844).

Danais echeria, Westw., Doubl. \& Hewits. Gen. Diurn. Lep. p. 91.

n. 2 (1847); Trimen, Rhop. Afric. Austral. p. 86 . n. 55 (1862).

D. vaillantiana, Godart, Enc. M. ix. p. 183. n. 25 (1819).

Hab. South Africa.

B.M.

\section{Danais egialea.}

Papilio egialea, Cramer, t. 192. f. D (1777).

Amauris egialea, Hübner, Verz. bek. Schmett. p. 14 (1816).

Danais egialea, Westw., Doubl. \& Hewits. Gen. Diurn. Lep. p. 91.

n. 3 (1847).

Hab. Ashanti.

B.M.

Note. - I have carefully compared all the figures of insects hitherto placed as synonyma of this species with the specimens in the National Collection, and I find that D. egialea and D. damocles are quite distinct. D. niavius (Gen. Diurn. Lep. pl. 11. f. 3) is also a separate species, only resembling Cramer's insect in coloration. 


\section{Danais damocles.}

Papilio damocles, Fabricius, Ent. Syst. iii. pt. 1. p. 41. n. 121 (1793) ; Pal. de Beauv. Ins. Afr. et Am. Lép. p. 238, t. 6. f. $3 a, 3 b$ (1805).

Danais damocles, Godart, Enc. M. ix. p. 182. n. 23 (1819).

Euploea damocles, Doubl. List Lep. Brit. Mus. p. 49 (1844).

Hab. Sierra Leone; Ashanti; Angola.

B.M.

Var. Front wings longer; hind wings entirely brown.

Hab. Gaboon.

B.M.

\section{Danais hecate, sp. $n$.}

Euploea niavius, Westw., Doubl. \& Hewits. Gen. Diurn. Lep. pl. 11. f. 3 (1847).

Differs from $D$. damocles in having the front wings longer and narrower, no white spot at the anal angle, the subapical row of spots further from the central band, and only the double central subapical spot large; the apical and costal spots are also much smaller; the hind wings shorter, more angular, more deeply sinuated along the outer margin, and more completely suffused with brown; the body longer in proportion to the hind wings.

Expanse of wings $3 \frac{1}{2}$ inches.

Hab. Ashanti.

B.M.

6. Danais ochlea.

Danais ochlea, Boisd. App. Voy. de Deless. p. 589; Trimen, Rhop. Afric. Austral. p. 85. n. 54.

Hab. Port Natal.

B.M.

7. Danais niavius.

Papilio niavius, Linn. Syst. Nat. ii. p.766.n. 109 (1767); Cramer,

t. 2. f. E, G (1775); Fabricius, Ent. Syst. iii. pt. 1. n. 120 (1793). Amauris niavius, Hübner, Verz. bek. Schmett. p. 14 (1816).

Danais niavius, Godart, Enc. M. ix.p. 182.n. 22 (1819); Westw., Doubl. \& Hewits. Gen. Diurn. Lep. p. 91. n. 4 (1847).

Var. Papilio niavius, Palisot de Beauvois, Ins. Afr. et Am. Lép. p. 288 , t. 6 . f. $1 a, 1 b$ (1805).

Hab. West Africa.

B.M.

Section 2 .

\section{Danais berenice.}

Papilio berenice, Cramer, pl. 205. f. E, F (1780).

Danais berenice, Boisd. et Leconte, Icon. Lép. et Chen. Am. Sept. t. 39 (1827); Westw., Doubl. \& Hewits. Gen. Diurn. Lepid. p. 91. n. 6 (1847); Wiedemeyer, Cat. North Amer. Butterf. p. 13 (1864). Papilio erippus, Fabricius, Ent. Syst. iii. pt. 1.p.49. n. 1 52 (1793). Danais erippus, Godart, Enc. M. ix. p. 186. n. 33 (1819). Anosia erippe, Hübner, Verz. bek. Schmett. p. 16 (1816). Papilio gilippus, Smith, Abb. Lep. Ins. of Georgia, i. t. 7 (1797). Hab. Georgia ; Florida. 
Var. a. Danais thersippus, H.W. Bates, Proc. Zool. Soc. (1863). Hab. Panama.

Var. b. Danais strigosa, H. W. Bates, Ent. Month. Mag. i. p. 33. n. $14(1864-65)$.

Hab. Jamaica.

Note-Danais jamaicensis (berenice, var.?), Bates, must be a variety of $D$. gilippus; it is described as differing from $D$. berenice in having the nervures of the hind wing margined with grey.

9. Danais cleothera (berenice, var.?).

Danais cleothera, Godart, Enc. M. ix. p. 185. n. 31 (1819); Westw., Doubl. \& Hewits. Gen. Diurn. Lep. p. 91. n. 7, t. 12. f. 2 (1847); Wiedemeyer, Cat. North Amer. Butterf. p. 13 (1864).

Hab. Haiti; Honduras; Venezuela.

B.M.

\section{Danais eresimus.}

Papilio eresimus, Cramer, pl. 175. f. G, H (1777) ; Fabricius, Ent. Syst. iii. pt. 1. p. 51. n. 157 (1793).

Danais eresimus, Godart, Enc. M.ix.p.185.n. 30 (1819); Westw., Doubl. \& Hewits. Gen. Diurn. Lep. p. 91 . n. 8 (1847).

Anosia eresima, Hübner, Verz. bek. Schmett. p. 16 (1816).

Hab. Brazil.

B.M.

\section{Danais gilippus.}

Papilio gilippus, Cramer, pl. 26. f. E, F (1775); Fabricius, Ent. Syst. iii. pt. 1. p. 52. n. 159 (1793).

Danais gilippus, Godart, Enc. M. ix. p. 186. n. 34 (1819); Boisd. Sp. Gén. i. t. 24. f. 2 (1837); Westw., Doubl. \& Hewits. Gen. Diurn. Lep. p. 91 . n. 5 (1847).

Limnas ferruginea vincetoxici, Hübner, Samml. exot. Schmett. (1806-27).

Anosia vincetoxici, Hübn. Verz. bek. Schmett. p. 16 (1816).

$H a b$. Brazil.

B.M.

Var. Danais jamaicensis (berenice, var.?), H. W. Bates, Ent. Month. Mag. i. p. 33 (footnote) (1864-65).

$H a b$. Guatemala.

B.M.

\section{Danais erippus.}

Papilio erippus, Cramer, t. 3. f. A, B (1775).

Danais erippus, Westw., Doubl. \& Hewits. Gen. Diurn. Lep. p. 91. n. 10 .

Papilio plexippus, Cramer, t. 206. f. E, F (1780).

P. archippus, Fabricius, Ent. Syst. iii. pt. 1.p. 49.n. 150 (1793);

Smith, Abb. Lep. Ins. of Georgia, i. t. 7 (1797).

Anosia archippus, Hübner, Verz. bek. Schmett. p. 16 (1816).

Danais archippus, Godart, Enc. M. ix. p. 184. n. 28 (1819); 
Wiedemeyer, Cat. North Amer. Butterf. p. 13 (1864); HerrichSchäffer, Schmett. Insel. Cuba, p. 4 (1864-65). Anosia megalippe, Hübn. Samml. exot. Schmett. (1806-27). Hab. Brazil ; Mexico; United States.

B.M.

\section{Danais cleophile.}

Danais cleophile, Godart, Enc. M. ix. p. 185. n. 32 (1819); Westw. Doubl. \& Hewits. Gen. Diurn. Lep. p. 91. n. 9, t. 12. f. 3 (1847); Weidemeyer, Cat. North Amer. Butterf. p. 13 (1864).

$H a b$. Haiti ; Jamaica.

B.M.

\section{Danais chrysippus.}

Papilio chrysippus, Linn. Syst. Nat. ii. p. 767 (1767); Cramer, ii. pl. 118. f. B, C ; Fabricius, Ent. Syst. iii. pt. 1. p. 50.

Danais chrysippus, Godart, Enc. M. ix. p. 187 ; Lép. de France, p. 106, pl. 27. f. 1, 2 ; Latreille, Dict. d'Hist. Nat. 2nd ed.t. 9. p. 118; Boisd. Ind. Meth. p. 14; Doubl. List Lep. Brit. Mus. pt. 1. p. 51; Westw., Doubl. \& Hewits. Gen. Diurn. Lep. p. 92. n. 14; F. Moore, Cat. Lep. Mus. East Ind. Comp. p. 126. n. 249, pl. 4. f. 7, 7 a (metamorph.); Trimen, Rhop. Afric. Austral. p. 88. n. 56.

Euploea chrysippus, Hübner, Verz. bek. Schmett. p. 15, t. 133.

f. 678,679 ; Herbst, t. 155 . f. 1, 2 ; Ochsenh. t. 4 , p. 120.

Papilio agyptius, Schreb. Ins. p. 9, f. 11, 12.

$H a b$. Europe; Asia; Africa; Oceania.

B.M.

Var. With the spots near the costa beyond the cell of front wings very large.

Hab. Hong Kong.

B.M.

Note.-All the specimens that I have seen of this species from Greece, Java, and Ceram are of a dull brownish colour.

\section{Danais alcippus (chrysippus, var.?).}

Papilio alcippus, Cramer, pl. 127. f. E, F (1777); Fabricius, Ent. Syst. iii. pt. 1.p. 50. n. 155 (1793); Herbst, Pap. t. 155. f. 5, 6.

Euploca alcippus, Hübner, Verz. bek. Schmett. p. 15 (1816); Ochsenh. t. 4, p. 120.

Danais alcippus, Godart, Enc. M. ix. p. 188. n. 9 (1819); Lép. de France, p. 110, pl. 17. f. 3 ; Boisd. Ind. Meth. p. 14; Doubleday, List Lep. Brit. Mus. p. 51 ; Westw., Doubl. \& Hewits. Gen. Diurn. Lep. p. 92 . n. 15.

Euploea dorippus, Klug, Symb. Phys. pl. 48. f. 1-5 (1829).

$H a b$. Sierra Leone; Ashanti; Italy (Godart).

B.M.

\section{Danais petilia.}

Papilio petilia, Stoll, t. 28. f. 3 (1790).

Danais petilia, Godart, Enc. M. ix. p. 189. n. 41 (1819); Doubl. List Lep. Brit. Mus. p. 51 (1844); Westw., Doubl. \& Hewits. Gen. Diurn. Lep. p. 92. n. 13 (1847).

Hab. Australia.

B.M. 


\section{Danais plexaure.}

Danais plexaure, Godart, Enc. M.ix. p.184.n.29(1819); Westw., Doubl. \& Hewits. Gen. Diurn. Lep. p. 92 . n. 12 (1847).

Hab. Brazil.

\section{Danais plexippus.}

Papilio plexippus, Linnæus, Syst. Nat. ii. p. 767 (1767) ; Fabricius, Ent. Syst. iii. pt. 1. p. 49.

Danais plexippus, Godart, Enc. M. ix. p. 186; Doubl. List Lep. Brit. Mus. pt. 1.p. 51 ; Westw., Doubl. \& Hewits. Gen. Diurn. Lep. p. 92 . n. 17 ; F. Moore, Cat. Lep. Mus. East Ind. Comp. p. 124. n. 246 , pl. 4. f. $6,6 a$ (metamorph.).

Euploa plexippus, Hübner, Verz. bek. Schmett. p. 15.

Papilio genutia, Cramer, iii. pl. 206. f. C, D (1780).

Hab. North India; China.

B.M.

\section{Danais philene.}

Papilio philene, Cramer, iv. pl. 375. f. A, B (1782).

Danais philene, Godart, Enc. M. ix. p. 187; Doubl. List Lep. Brit. Mus. pt. 1. p. 50 ; Westw., Doubl. \& Hewits. Gen. Diurn. Lep. p. 92. n. 17; F. Moore, Cat. Lep. Mus. East Ind. Comp. p. 124. n. 245 , pl. 4. f. 5, $5 a$ (metamorph ).

Euploea philene, Hübner, Voy. bek. Schmett. p. 15.

Hab. Java; Amboyna.

B.M.

D. philene, var., intermediate between this species and the next. $\mathrm{Hab}$. Gilolo.

B.M.

20. Danais artenice (philene, var.?).

Papilio artenice, Cramer, pl. 375. f. C, D (1782).

Danais artenice, Godart, Enc. M. ix. p. 187.n. 36(1816); Westw., Doubl. \& Hewits. Gen. Diurn. Lep. p. 92 . n. 18 (184i).

Euplaa artenice, Hübner, Verz. bek. Schmett. p. 15 (1816).

Hab. Java.

B.M.

Note.-I have compared our specimens of D. philene and D. artenice with Cramer's figures, and I find that neither the subapical markings of the front wings nor the white streaks in the hind wings are reliable as distinguishing characters; the insects also appear to vary considerably in size and outline.

21. Danais pullata, sp. n.

Upperside copper-brown, darker towards the base. Front wings with an elbowed subapical series of five white spots, as in the allied species; a minute spot beyond the middle of the costa; a short double series of submarginal spots at the centre of the hind margin; an apical white spot. Hind wings with a double or single series of minute submarginal white dots. Body-thorax black brown, spotted with white; antennæ black; abdomen brown, orange below.

Underside dull ferruginous; nervures brown. Front wings with- 
out an apical spot, with several additional submarginal dots near the apex ; otherwise as above. Hind wings clouded with brown towards the base; a complete double series of white submarginal spots along the hind margin, and a white spot beyond the middle of the costa.

Expanse of wings $3 \frac{5}{16}$ inches.

Hab. Dory.

B.M.

Fig. 1 .

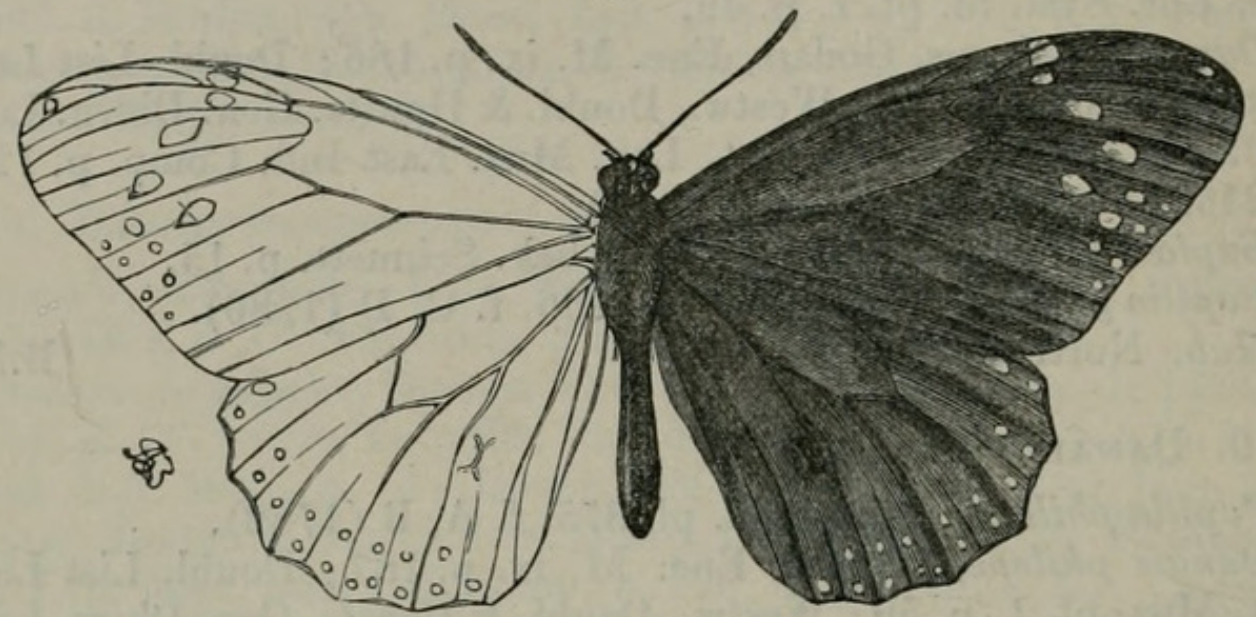

Danais pullata.

\section{Danais affinis.}

Papilio affinis, Fabricius, Ent. Syst. iii. pt. 1. p. 58. n. 181.

Danais affinis, Godart, Enc. M. ix. p. 182. n. 21 (1819); Westw., Doubl. \& Hewits. Gen. Diurn. Lep. p. 92. n. 20 (1847); Blanch. Voy. au Pôle Sud, p. 389 (Insectes), pl. 2. f. 7.

Danais cecilia, Bougainville, Voy. de la Corvette Thétis, t. 44. f. 3,3 bis (1837).

Hab. Amboyna; Borneo.

B.M.

\section{Danais fulgurata, sp. n. (Pl. IV. fig. 1).}

Upperside dark brown; an elongate streak near the inner margin of front wings and five streaks between the nervures in the centre of hind wings ferruginous. Front wings with white markings of apical half as in $D$. philene ; a large elongate white spot in the centre of the ferruginous streak. Hind wings with a white irregular band across the cell, running nearly parallel to the costa, and divided into five portions by the nervures; towards the abdominal margin dusky ; inner margin pale brown, with a marginal row of small white spots; cilia white. Body-thorax brown; head and prothorax speckled with white; abdomen pale brown.

Underside-front wings, basal half pale ferruginous, inclining to brown towards the costa ; apical half brown, an irregular white blutch below the base of the first median nervule; several additional submarginal spots; otherwise as above. Hind wings ferruginous; nervures black; three small white spots at the base, close to the body; a white spot below the base, and another below the apex of the costal nervure; outer margin dusky ferruginous, a complete double series 
of submarginal white spots ; central band more irregular than above, extended down the abdominal margin to the anal angle. Bodyabdomen rather paler; otherwise as above.

Expanse of wings $2 \frac{6}{8}$ inches.

Hab. Celebes.

24. Danais conspicua, sp. n. (Pl. IV. fig. 2.)

D. silena, Bdv. MS.

Upperside-front wings as in D. philene. Hind wings ferruginous, not so dark as the front wings; nervures and outer margin dark brown; cell, a submarginal series of dots, double at the anal angle, and two subapical spots between the nervures white. Body-head and prothorax black, spotted with white; meso- and metathorax dark grey; abdomen pale ferruginous.

Underside-front wings, apex copper-brown; several additional submarginal dots; otherwise as above. Hind wings dull orange ; cell white, irrorated with orange scales; a complete double submarginal series of white spots; five white spots near the apical hind margin between the nervures; otherwise as above.

Expanse of wings $3 \frac{2}{8}$ inches.

Hab. Celebes.

B.M.

\section{Danais melanippus.}

Papilio melanippus, Cramer, ii. t. 127. f. A, B (1777).

Danais melanippus, Godart, Enc. M. ix. p. 189 ; Doubleday, List Lep. Brit. Mus. pt. 1. p. 50 ; F. Moore, Cat. Lep. Mus. East Ind. Comp. p. 125. n. 247.

Euploea hegesippus, Hübner, Verz. bek. Schmett. p. 15 .

Danais hegesippus, Godart, Enc. M. ix. p. 189 ; G. R. Gray, Lep. Ins. of Nepal, p. 10, t. 9. f. 1 ; Doubleday, List Lep. Brit. Mus. pt. 1. p. 50 ; Westw., Doubl. \& Hewits. Gen. Diurn. Lepid. p. 92. n. 19 ; F. Moore, Cat. Lep. Mus. East Ind. Comp. p. 125. n. 247 (melanippus, var.).

Hab. India ; Sumatra; Java.

B.M.

Var. Papilio hegesippus, Cramer, ii.t.180. f. A (1779); Fabricius, Ent. Syst. iii. pt. 1. p. 52 .

Hab. Java (B.M. and Horsf. Coll.).

26. Danais lotis.

Papilio lotis, Cramer, iii. pl. 230. f. D, E (1780).

Danais lotis, Godart, Enc. M. ix. p. 189; Westw., Doubl. \& Hewits. Gen. Diurn. Lep. p. 92. n. 21 ; Doubl. List Lep. Brit. Mus. App. (1848) p. 13; F. Moore, Cat. Lep. Mus. East India Comp. p. 125. n. 248.

Hestia thoë, Hübner, Verz. bek. Schmett. p. 15 (1816).

Danais edmondi, Bougainville, Voy. de la Corrette Thétis, t. 44. f. 3,3 bis $(1837)$.

Hab. Amboyna; Borneo. B.M.

Proc. Zool. Soc.-1866, No. IV. 


\section{Danais ismareola, sp. $n$.}

Upperside-front wings brown; a white discoidal streak; three elongate obliquely placed white spots at the end of the cell; a series of six white spots across the disk, the three upper ones placed obliquely, the others following the direction of the outer margin; a double submarginal series of white spots; a large white apical spot; a large white spot below the end of the cell, between first and second median branches; an elongate white streak filling the interspace between the first median branch and the submedian nervure to beyond the middle of the wing; a narrow white streak along the interior margin. Hind wings, basal area white, divided into thirteen unequal parts by the nervures, which are brown; outer margin brown, with a double series of submarginal white spots. Body brown; prothorax spotted with white.

Underside nearly as above. Body-abdomen pale brown.

Expanse of wings $3 \frac{9}{16}$ inches.

Hab. Ternate.

B.M.

28. Danais ismare.

Papilio ismare, Cramer, pl. 279. f. E, F (1780).

Hestia ismare, Hübner, Verz. bek. Schmett. p. 15 (1816).

Danais ismare, Godart, Enc. M. ix. p. 190. n. 45 (1819); Westw., Doubl. \& Hewits. Gen. Diurn. Lepid. p. 93. n. 31 (1847).

Hab. Amboyna; North Ceram.

B.M.

Section 3 .

\section{Danais sobrina.}

Danais sobrina, Boisd. Faune de l'Océanie, ix. p. 103, pl. 4. f. 3 (1832); Westw., Doubl. \& Hewits. Gen. Diurn. Lepid. p. 92 . n. 24 (1847).

Hab. New Guinea.

B.M.

Note.-In the 'Voyage de l'Astrolabe,' the island of Vanikoro is given as the locality for this species; but this may possibly be an error. I have lately seen specimens from the Aru Islands.

30. Danais similis.

Papilio similis, Limnæus, Syst. Nat. i. p. 479 (1758); ii. p. 782 ; Clerck, Icones, t. 16. f. 3 .

Danais similis, Doubleday, List Lep. Brit. Mus. pt. 1.p.49 (1844); Westw., Doubl. \& Hewits. Gen. Diurn. Lepid. p. 92 . n. 30 (1847); F. Moore, Cat. Lep. Mus. East Ind. Comp. p. 122. n. 237 (1857).

Papilio aventina, Cramer, i. pl. 59. f. F (1775).

Danais aventina, Godart, Enc. M. ix. p. 191.

$H a b$. China; Java; North India.

B.M.

Var. Danais melissa, Doubleday, List Lep. Brit. Mus. pt. 1. p. 49; Westw., Doubl. \& Hewits. Gen. Diurn. Lep. p. 92. n. 28.

$H a b$. North India; Singapore.

B.M.

Note.-This variety was formerly in the National Collection under the name of $D$. melissa. 


\section{Danais meganira.}

Danais meganira, Godart, Enc. M.ix. p.192.n. 51 (1819); Boisd. Faune de l'Océanie, ix. p. 104. n. 3 (1832); Westw., Doubl. \& Hewits. Gen. Diurn. Lep. p. 92. n. 29 (1847); Blanch. Voy. au Pôle Sud, p. 387 , pl. 2. f. 4 .

Hab. Java; Ceram; Philippine Islands.

B.M.

Var. Rich reddish brown on a greenish ochreous ground; the nervures much more broadly bordered, and the spots consequently smaller.

$H a b$. Ceram.

B.M.

32. Danais melissa.

Papilio melissa, Cramer, iv. pl. 377. f. C, D (1782); Herbst, Pap. t. 125. f. 3, 4.

Danais melissa, Godart, Enc. M. ix. p. 192 ; F. Moore, Cat. Lep. Mus. East Ind. Comp. p. 121. n. 236.

Hab. Java; North India. (Horsf. Coll.).

33. Danais xanthippus.

Danais xanthippus, Felder, Wien. Ent. Monatsschr. iv. p. 100. Hab. Brazil.

\section{Danais liminiace.}

Papilio limniaca, Cramer, i. pl. 59. f. C, D (1775).

Danais limniace, Godart, Enc. M. ix. p. 191; Doubleday, List Lep. Brit. Mus. pt. 1. p. 49 ; Westw., Doubl. \& Hewits. Gen. Diurn. Lepid. p. 93. n. 31 ; F. Moore, Cat. Lep. Mus. East Ind. Comp. p. 121 . n. 235, pl. 4 . f. $3,3 a$ (metamorph.).

Papilio similis, Fabricius, Ent. Syst. iii. pt. 1. p. 58.

Euploea hamata, M'Leay, King's Survey of Australia, ii. App. p. 46 (1827).

Hab. Java; North India; Penang.

B.M.

Var. With all the markings much narrower; abdomen with very large yellow anal tuft.

Hab. Borneo.

B.M.

35. Danais leonora, sp. n. (limniace, var.?).

Upperside-front wings black brown, with pale-greenish semitransparent spots, which differ from those of $D$. limniace in being broader and shorter; no streak helow the base of the submedian nervure. Hind wings much smaller and rounder than those of $D$. limniaca; the cells much shorter; rich olive-brown, with palegreenish semitransparent spots, which differ from those of $D$. limniacce in being broader and shorter.

Underside as above, excepting that the apical portion of the front wing is of an olive-brown colour, and the interior margin reddish; the hind wing is also paler.

Expanse of wings $3 \frac{9}{16}$ inches.

Hab. Angola. 
Note.-We have three specimens of this insect in the National Collection, and all of them agree in colouring.

\section{Danais leopardus, sp. n. (Limniace, var.?).}

Upperside differs from the preceding in having all the wings olivebrown. Front wing with larger and more yellowish spots and streaks, also a large patch on each side of the submedian nervure near the base, as in D. meganira. Hind wings with pale-ochreous spots and streaks ; the cell a little longer than in $D$. leonora, but not so long as in D. limniucre.

Underside as above, excepting that the apical portion of the front wings is of a golden brown colour, and the interior margin reddish; the hind wings are also golden brown.

Expanse of wings $3 \frac{15}{16}$ inches.

$H a b$. India (three specimens).

B.M.

37. Danais australis (Limniacae, var.?).

Danais australis, Boisduval ; Blanchard, Voy. au Pôle Sud (Insectes), p. 388, pl. 2. f. 5, 6 .

Hab. New Holland (Raffles Bay).

\section{Danais choaspes, sp. $n$.}

Upperside with a faint greenish gloss. Front wings dark olivaceous brown; a narrow short discoidal white line extending to near the middle of the cell; a very irregular oblique white band, divided by the dark nervures into four unequal semitransparent white spots, extending from the costal nervure and end of cell to the submedian nervure ; five obliquely placed irregular elongate white spots beyond the end of the cell; a double submarginal series of white spots, the inner series, except the first, fifth, and seventh, large and elongate. Hind wings, basal area white, semitransparent, divided by the nervures, which are brown, into twelve unequal parts; outer margin broadly olivaceous brown, with a double submarginal series of white spots, the inner series elongate, alternately small and large. Body, head, and thorax olivaceous brown, spotted with yellow; abdomen creamy white.

Underside - front wings, apical portion olive-green ; centre of disk inclining to bluish; base and inner margin reddish brown; spots iridescent; otherwise as above. Hind wings olive-green, instead of olivaceous brown; spots faintly iridescent; otherwise as above.

Expanse of wings $3 \frac{3}{16}$ inches.

Hab. Celebes.

\section{Danais purpurata, sp. n.}

Male. Front wings elongate. Upperside-front wings, basal area semitransparent, divided by dark-brown nervures into three unequal parts ; the cell interrupted by a central brown band; front and hind margins brown, a minute greenish spot on the subcosial nervure beyond the middle of the cell ; four spots beyond the cell, the lowest 
one, below the base of the first median branch, the largest; three elongate subcostak, three irregularly placed subapical, and five small circular white apical submarginal spots. Hind wings, basal area pale greenish, divided by the brown nervures into ten to eleven differently formed portions; outer margin broadly brown, with a submarginal series of five to eight small white spots. Body brown; head and prothorax spotted with white; abdomen pale brown.

Underside-front wings, apex glossed with purplish ; inner margin pale brown, several additional submarginal white dots; otherwise as above. Hind wings, outer margin glossed with purplish; a double series of submarginal spots; inner margin ochreous; otherwise as above.

Female. Wings rounded, shorter and broader than in male. Colours the same.

Expanse of wings $3 \frac{3}{16}$ inches.

$H a b$. New Guinea.

B.M.

Fig. 2.

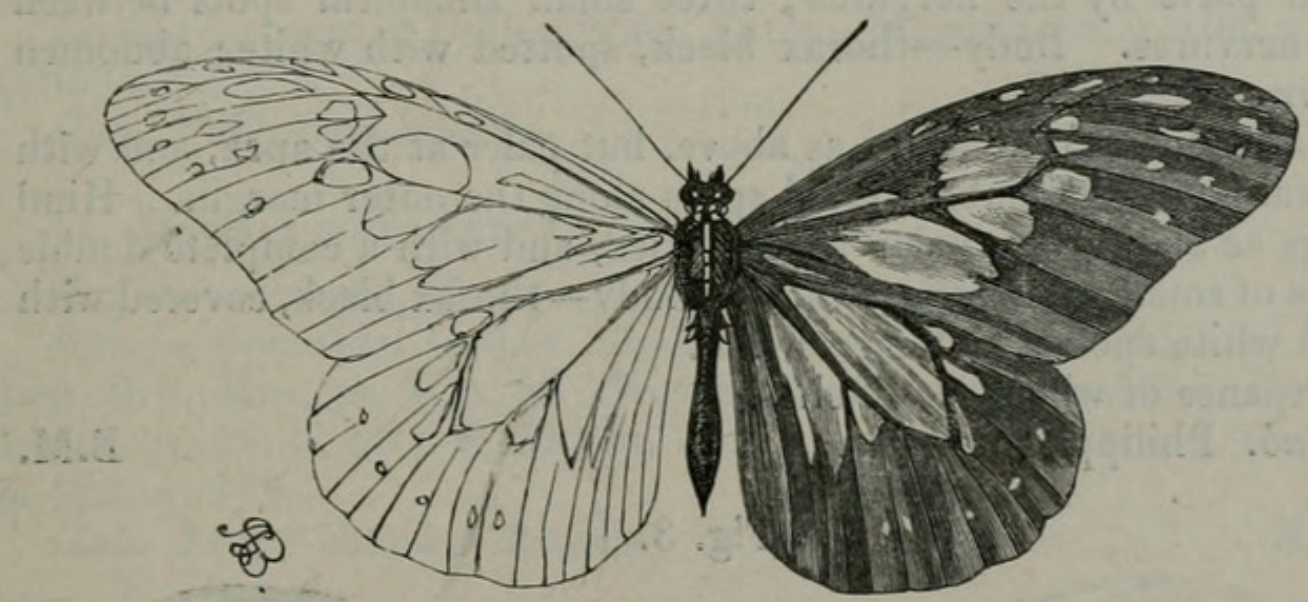

Danais purpurata.

40. Danais fumata, sp. $n$.

Upperside - front wings rich brown, with a long discoidal streak; a large patch below the median nervure, extending from the base to the middle of the third median branch; two spots between the first and second median branches, one in the middle, and one at the base of the nervules; three submarginal spots, one below each of the median branches; an oblique band from beyond the middle of the costa to the middle of the third median branch, divided into five spots by the nervures; two minute spots near the end of the cell, below the third median branch, and two small obliquely placed subapical spots, pale-greenish white, semitransparent. Hind wings rich brown, interior margin paler; cell, a short streak above its termination, a minute streak near the costa beyond the middle, a minute spot beyond the end of the cell, a subapical row of three small spots, and a submarginal row of four minute dots pale greenish white, semitransparent. Body brown.

Underside-wings golden brown; a patch of darker colour below 
the end of hind-wing cell ; markings nearly as above ; only one subapical spot in front wings; the cell almost entirely white to near its termination. Hind-wing cell with a central brown streak; submarginal dots larger, seven in number. Body-thorax black, spotted with yellow ; abdomen pale ochreous.

Expanse of wings $3 \frac{1}{16}$ inches.

Hab. Ceylon.

B.M.

\section{Danais erebus, sp. $n$.}

Upperside smoky brown, all the markings hyaline. Front wings, basal area divided into three unequal transparent parts; a brown streak above the inner margin; six nearly equidistant spots in the form of a triangle, from the third median branch to the anal angle ; a short oblique band divided into five unequal elongate spots by the nervures, from the costa to beyond the middle of the third median branch; a submarginal series of spots, becoming gradually larger towards the costa. Hind wings, basal area divided into twelve unequal parts by the nervures; three small subapical spots between the nervures. Body-thorax black, spotted with white; abdomen brown.

Underside-front wings as above, but paler at the apex, and with several additional submarginal spots along the outer margin. Hind wings as above, but paler at the apex, and with a complete double series of small submarginal spots. Body-thorax black, covered with large white spots; abdomen white.

Expanse of wings $2 \frac{15}{16}$ inches.

$H a b$. Philippine Islands.

B.M.

Fig. 3 .

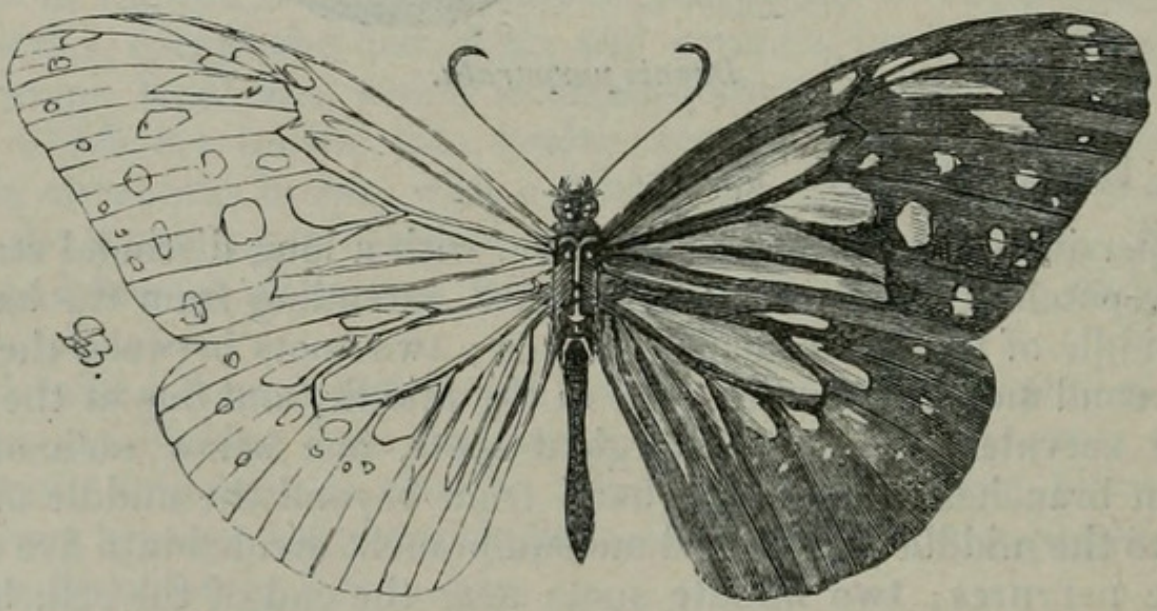

Danais erebus.

\section{Danais aglea.}

Papilio aglea, Cramer, iv. pl. 377. f. E (1782).

Danais aglea, Doubleday, List Lep. Brit. Mus. pt. 1.p. 50 (1844); Westw., Doubl. \& Hewits. Gen. Diurn. Lepid. p. 92. n. 22 (1847); F. Moore, Cat. Lep. Mus. East Ind. Comp. p. 122. n. 239 (1857). Hab. Java. 
43. Danais agleoides.

Danais agleoides, Felder, Wien. Ent. Monatsschr. iv. p. 398. $H a b$. Malayan peninsula.

B.M.

44. Danais grammica (D. aglea, var.?).

Danais grammica, Boisduval, Spéc. Gén. Lép. i. t. 11.f. 10 (1836); Doubl. List Lep. Brit. Mus. pt. 1. p. 50 (1844); Westw., Doubl. $\&$ Hewits. Gen. Diurn. Lepid. p. 92 . n. 23 (1847); F. Moore, Cat. Lep. Mus. East Ind. Comp. p. 122. n. 238 (1857).

Hab. Java.

B.M.

45. Danais phyle.

Danais phyle, Felder, Wien. Entom. Monatsschr. p. 105. n. 65 (1863).

Hab. Philippine Islands.

46. Danais luzonensis.

Danais luzonensis, Felder, Wien. Entom. Monatsschr. p. 106. n. 66 (1863).

$H a b$. Philippine Islands.

47. Danais melaneus.

Papilio melaneus, Cramer, i. t. 30. f. B (1775).

Danais melaneus, Godart, Enc. M. ix. p. 192; Doubleday, List Lep. Brit. Mus. pt. 1. p. 50; Westw., Doubl. \& Hewits. Gen. Diurn. Lepid. p. 93. n. 36 ; F. Moore, Cat. Lep. Mus. East Ind. Comp. p. 123. n. 242.

Hab. Java ; China; Penang.

B.M.

48. Danais tytia.

Euploea tytia, G. R. Gray, Lep. Ins. of Nepal, p. 9, t. 9. f. 2 (1846).

Danais tytia, Doubleday, List Lep. Brit. Mus. pt. 1. p. 50 (1844); Westw., Doabl. \& Hewits. Gen. Diurn. Lepid. p. 93. n. 35, t. 12. f. 4 (1847) ; F. Moore, Cat. Lep. Mus. East Ind. Comp. p. 123. n. 243 (1857).

$\mathrm{t}, 6$.

Danais tita, Kollar in Hügel's Reise n. Kaschmir, App. p. 424, Hab. North India.

B.M.

49. Danais albata.

Euploa albata, Zinken-Sommer, in Nova Acta Acad. Curios. xv. t. 16 . f. 16 (1831).

Danais albata, Doubl. List Lep. Brit. Mus. pt. 1. p. 50 (1844); Westw., Doubl. \& Hewits. Gen. Diurn. Lepid. p. 93. n. 37 (1847). D. ablata (misprint?), F. Moore, Cat. Lep. Mus. East Ind. Comp. p. 124. n. 244 (1857).

Hab. Java.

B.M. 


\section{Danais enone (D. vitrina, Felder?).}

Male. Upperside-wings hyaline, the same form as in D. cleona, $\delta$; nervures, end of front-wing cell, and margins black; hind margins broadly black. Front wings, basal area divided by the nervures into four parts; subapical patch in three parts; three costal and seven submarginal spots. Hind wings with a large basal area, divided by the nervures into twelve unequal parts; a doulsle series of submarginal brown spots, two or three of which are pupillated with white at the apex and anal angle. Body - thorax black, with creamy spots; abdomen white, with a dorsal black line.

Underside-front wings with a submarginal row of fourteen minute white spots in couples along the hind margin; otherwise as above. Hind wings with a double submarginal row of white, not brown, spots; otherwise as above. Body-thorax black, with numerous creamy spots; abdomen white.

Expanse of wings $2 \frac{11}{16}$ inches.

ㅇ․ D. ønone, A. G. Butler, P.Z. S. 1865, p. 433, pl. xxv. f. 6.

Hab. Philippine Islands.

B.M.

Note.- It has been suggested to me that I was wrong in describing this species, on the score of its being "nothing more than D. albata;" but when the two insects are placed side by side, I think that few entomologists would deny that they are very distinct. The hindwing cell in D. albata is much broader, the fore wing more convex in front, the wings not so transparent, the marginal and subapical spots much larger and more numerous, the hind-wing disk almost entirely suffused with brown, the submarginal spots all white: considering these points of distinction, as well as the difference of locality, I think I should be scarcely justified in sinking my species into a synonym of $D$. albata. It may, however, be identical with $D$. vitrina of Felder; but it is almost impossible to recognize such closely allied species without figures.

\section{Danais vitrina.}

Danais vitrina, ơ, Felder, Wien. Entom. Monatsschr. p. 300. n. 10 (1861).

$H a b$. Philippine Islands.

B.M.

\section{Danais gloriola, sp. n. (Pl. IV. figs. 3 ; 4.)}

Male. Upperside-wings the same form as in D. cleona, $\delta^{*}$, bright transparent yellow, increasing in intensity towards the base; nervures black. Front wings, anterior margin, base, upper half of cell, apex, hind margin, inner margin from the anal angle to the middle of the third median branch, and an irregular oblique band from the end of the cell to near the middle of the hind margin black brown; a very indistinct series of minute submarginal white dots. Hind wings, base brown; basal area divided into ten unequal parts; outer margin broadly brown. Body, head, and prothorax black, spotted with white; the rest of the body brown.

Underside-front wings, submarginal series of spots more distinct; 
otherwise as above. Hind wings with a very irregular double series of white submarginal spots; inner margin and costa beyond the middle pale; otherwise as above. Body - thorax black, with white spots at the base of the wings; palpi white; abdomen pale brown.

Female. Wings the same shape as in D. cenone, $q$. Differs from the male in colouring as follows:-Upperside paler yellow. Front wings brown ; subapical cross band with an irregular central oblique downward branch terminating just below the second median nervule; outer margin with a distinct series of white spots. Hind wings, an indistinct submarginal series of minute white dots.

Underside-front wings with large submarginal spots, and a partially defined outer series of smaller spots. Hind wings, double series of submarginal spots much more regular and complete.

Male and female. Expanse of wings $2 \frac{6}{8}$ inches.

Hab. Aru Islands.

B.M.

Female. Var. Transparent white, yellow towards the base. Front wings, subapical cross band wider, with more broadly extended downward branch. Hind wings, series of submarginal spots more distinct.

Hab. Ké Island.

B.M.

53. Danais crocea, sp. n. (Dorippa, Boisd. MS.). (Pl. IV. figs. 5, 6.)

Allied to D. cleona, Cramer, from which it differs in having the cell of front and the costa of hind wings unclouded; the subapical and submarginal spots more numerous, and white, not yellow; an additional yellow spot below the base of the third median nervule; the nervures not so broadly margined with brown, and the wings more transparent. Underside the same as above.

Expanse of wings, ơ, $2 \frac{1}{2}-3 \frac{1}{8}$ inches; $q, 2 \frac{5}{8}-3 \frac{3}{16}$ inches.

$H a b$. Java; India; Borneo.

B.M.

Note.--In some specimens the whole transparent portion of the front wing is clear white, with a slight tinge of yellow at the base.

\section{Danais cleona.}

Papilio cleona, Cramer, Pap. Exot. iv. t. 377. f. F (1782).

Danais cleona, Godart, Enc. M. ix. p. 190 ; Doubleday, List Lep. Brit. Mus. pt. 1. p. 50 ; Westw., Doubl. \& Hewits. Gen. Diurn. Lepid. p. 92. n. 27; Blanch. Voy. au Pôle Sud, p. 386, pl. 2. f. 3 ; F. Moore, Cat. Lep. Mus. East Ind. Comp. p. 123. n. 241.

Var. Euploea philomela, Zinken-Sommer in Nova Acta Acad. Curios. xv. t. 16. f. 17 (1831).

Hab. Java; North India; Borneo; Moluccas.

B.M.

Female. Var. Wings larger and broader; the cell of hind wings rather longer ; cell of front wing nearly clear yellow, scarcely showing the central brown blotch.

Expanse of wings $2 \frac{1}{16}$ inches.

Hab. Ternate. 
55. Danais mariana. (Pl. IV. fig. 7.)

Danais mariana, Butler, Ann. \& Mag. Nat. Hist. (1865), xvi. 397. Hab. New Caledonia.

B.M.

Section $3 a$.

56. Danais inuncta. (Pl. IV. fig. 8.)

Dañais inuncta, Butler, P. Z. S. 1865, p. 481.

Hab. Waigiou.

B.M.

57. Danais vitrea.

Danais vitrea, Blanchard, Voy. au Pôle Sud, p. 385, pl. 2. f. 2. D. cenopia, Felder, Wien. Entom. Monatsschr. t. 4. f. 2 (1859). $H a b$. New Guinea; Celebes.

B.M.

58. Danais chloris.

Danais chloris, Felder, Wien. Entom. Monatsschr. iv. p. 231. Hab. Celebes?

59. Danais anapis.

Danais anapis, Felder, Wien. Entom. Monatsschr. p. 300. n. 11 (1861).

Hab. Philippine Islands.

Note.-Felder says of this species that it belongs to the section in which $D$. vitrea is, but is marked like D. gaura.

\section{Section 4.}

60. Danais gaura.

Idea? gaura, Horsfield, Col. Lep. Mus. East Ind. Comp. t. 6. f. I (1829); Boisduval, Sp. Gén. Lép. pl. 11.f. 11.

Hestia gaura, Doubleday, List Lep. Brit. Mus, pt. 1. p. 52.

Danais gaura, Westw., Doubl. \& Hewits. Gen. Diurn. Lep, p. 93. n. 38 .

Ideopsis gaura, F. Moore, Cat. Lep. Mus, East Ind. Comp. p. 134. n. 266 .

Hab. Java.

B.M.

61. Danais daos.

Idea daos, Boisduval, Sp. Gén. Lép. i. pl. 24. f. 3 (1836).

Hestia daos, Doubleday, List Lep. Brit. Mus.pt. 1.p. 52 (1844).

Danais daos, Westw., Doubl. \& Hewits. Gen. Diurn. Lepid. p. 92.

n. 39 (1847).

Ideopsis daos, F. Moore, Cat. Lep. Mus. East Ind. Comp. p. 134. n. 267 (1857).

Hestia eudora, G. R. Gray, in Cat. Lep. Ins. of Nepal. p. 10, t. 9. f. 3 (1846).

Hab. Singapore; Penang.

Var. Idea diardi, Van der Hoeven, Tijdschr. voor Ent. (1860) pt. 3, p. 44, pl. 2. f. 4 .

Hab. Hong Kong.

B.M. 
c 


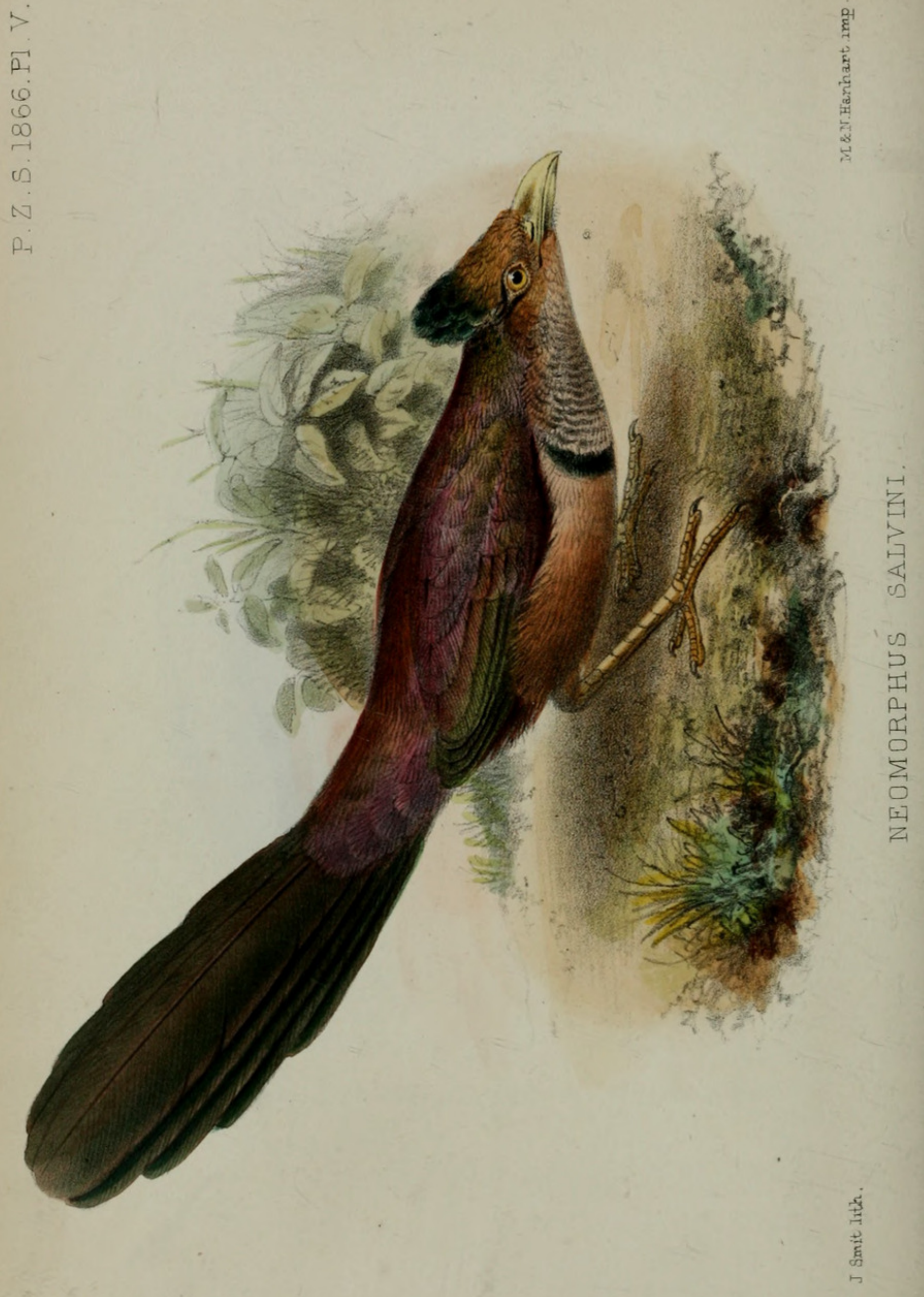


Note.-Dr. Herrich-Schäffer, in his 'Lepidopterorum Index Systematicus,' gives names to four speciès in this genus (D. schenckii, arema, hermippe, and nerippe). Dr. Boisduval has also named several species, some of which (D. nerippe, azema, lixa, and daulis) have been immortalized in Mr. Doubleday's 'Genera.' I am not, however, able to make use of these names, as I have not seen the insects for which they are intended.

\section{EXPLANATION OF PLATE IV.}

Fig. 1. Danais fulgurata, p. 48 .

2. conspicua, p. 49.

3, 4. - gloriola, p. 56 .
Figs. 5, 6. Danais crocea, p. 57 .

7. - mariana, p. 58.

8. — inuncta, p. 58.

4. On a New American Cuckoo of the Genus Neomorphus. By P. L. Sclater, M.A., Ph.D., F.R.S., Secretary to the Society.

\section{(Plate V.)}

In a note upon the Cuckoos of the genus Neomorphus, published in the Society's ' Proceedings' for 1864 , I pointed out the characters which separated the two species of this peculiar genus then known to me, and gave some information as to their geographical distribution. In the series of birds lately received by Mr. Osbert Salvin from Veragua, a specimen of what appears to me to be a third species of the genus occurs. Knowing the interest I take in this group, Mr. Salvin has kindly handed the bird over to me for comparison; and I propose to call it, after my friend who has devoted so much time and toil to the Natural History of Central America, Neomorphus salvini.

Curiously enough this new northern species of Neomorphus is much more nearly allied to the Brazilian $N$. geoffroyi than to $N$. rufipennis of Guiana and Amazonia. It is, however, in my opinion, quite sufficiently distinct to merit specific separation, and will, I think, be readily recognized by the characters given in the following synopsis of the species of the genus which have come under my observation :-

\section{Genus Neomorphus.}

Neomorphus, Gloger, Froriep's Notizen, 1827, p. 278.

Cultrides, Pucheran, Rev. Zool. 1851, p. 211.

a. Sp. torque collari angusto : rostro virescente, basi plumbeo : alis extus æneo-purpurascentibus.

\section{NEOMORPHUS GEOFFROYI.}

Coccyzus geoffroyi, Temm. Pl. Col. 7 ; Max. Beitr. iv. 324 .

Cultrides geoffroyi, Puch. R. Z. 1851, p. 211 ; Burm. Syst. Ueb. ii. p. 258 . 
Neomorphus geoffroyii, Cab. et Hein. Mus. Hein. iv. p. 91 ; Sclater, P. Z. S. 1864, p. 249.

Rostro elongatiore: capitis antici plumis fusco-rufis, purpurascente terminatis : supra aneo-viridis, purpurascente tinctus.

Hab. Brasil. or.

Mus. Brit. Vindob. et P. L. S.

Natterer collected several examples of this species (his no. 1077) in the vicinity of Pará.

2. Neomorphus salvini, sp. nov. (Pl. V.)

Rostro minus elongato, magis alto: capitis antici plumis omnino rufis : supra, prasertim in secundariis externis et cauda tectricibus superioribus, magis purpurascens.

Long. tota 19 , alæ $6 \cdot 5$, caudæ $10 \cdot 5$, tarsi $2 \cdot 7$, poll. Angl.

Hab. Veragua.

Mus. Brit. et O. Salvin.

Besides Mr. Salvin's specimens, there is an example of this species in the British Museum, stated to be from New Granada, which agrees with it in all its essential characters. The most noticeable of these are the shorter and much more elevated beak and the uniform rufous colour of the front part of the head.

b. Sp. torque collari lato: rostro distincte bicolore, nigro, apice corneo : alis extus rufis.

\section{Neomorphus RUfipenNis.}

Cultrides rufipennis, G. R. Gray, P. Z. S. 1849, p. 63, pl. 10.

Neomorphus rufipennis, Cab. et Hein. Mus. Hein. iv. p. 92 ; Sclater, P. Z. S. 1864, p. 249.

Supra late virescens, occipite cristato et dorso summo purpurascentibus: alis extus late rufis: tectricibus minoribus dorso concoloribus : subt us ochracescenti-cinereus : torque collari lato, bipollicari, purpurascenti-nigro: gulce plumis cinereis, nigro partim marginatis: rostro nigro, apice utriusque mandibula distincte pallide corneo : pedibus corneis.

Long. tota $19 \cdot 5$, alæ $6 \cdot 5$, caudæ $10 \cdot 8$, tarsi 3.8 .

Hab. Guiana Brit.

Mus. Brit. et Vindob.

Since I wrote the article above referred to on this species, I have seen a specimen in the Vienna Museum obtained by Natterer in Northern Brazil, on the Rio Brancho, at the foot of the small mountain Arimani; it bears his no. 1029.

I am still uncertain as to whether the Cultrides pucherani of Deville, figured in Castelnau's Voyage, belongs to this species or not. If different, it will form a second species of the same section. 


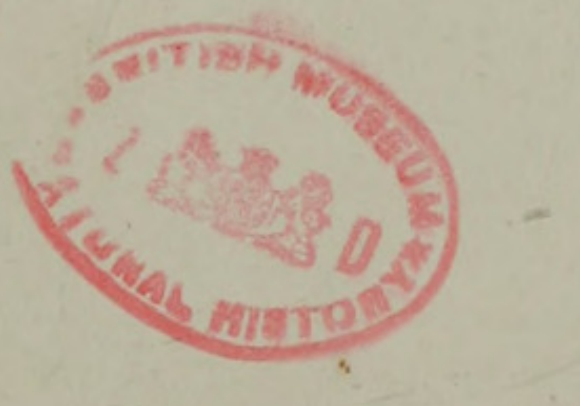




\section{P.Z.S.1866, P1.VI.}

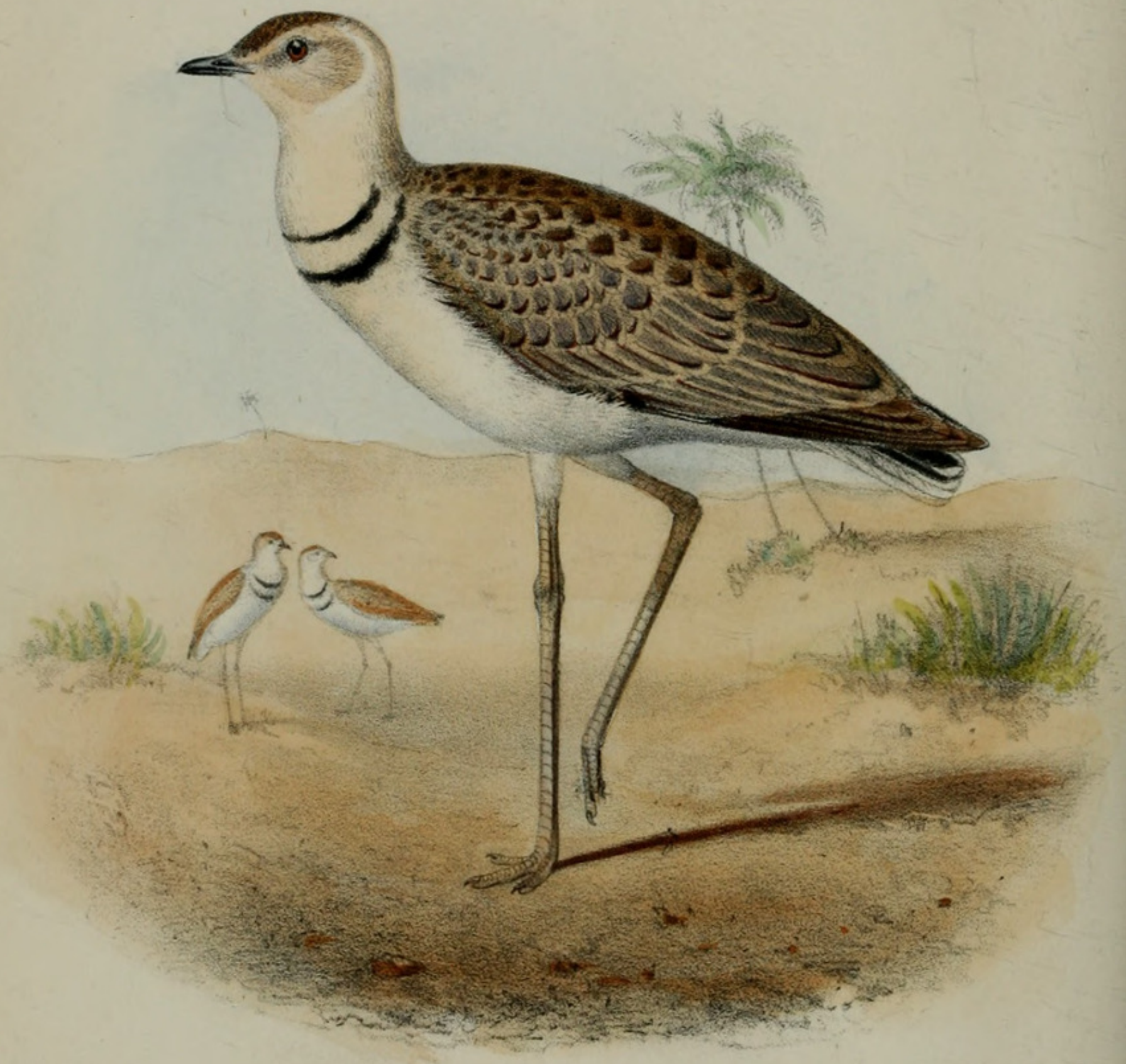


5. Synopsis of the Genus Cursorius.

By Dr. G. Hartlaub, F.M.Z.S.

(Plate VI.)

a. Rostro longiore, culmine rotundato; digitis pro mole longioribus ; fascia occipitali duplici, superiore nigra, inferiore alba, fascia caudæ anteapicali nigra.

1. Cursorius gallicus (Gm.).

C. europaeus, Lath.

C. isabellinus, Meyer; Salvin, Ibis, 1859, pp. 79, 354 .

$H a b$. in Europa merid. et Africa sept.

2. Cursorius rufus, Gould.

C. rufus, Gould, P. Z. S. 1836, p. 81; Icon. Av. pl. 10.

Tachydromus burchelli, Sw. Anim. Menag. p. 340 ; Gurney, Ibis, 1860, p. 217 ; Schleg. Mus. Pays-Bas, livr. 7. p. 13.

Hab. in Africa merid. (Mus. Brem.).

3. Cursorius Senegalensis, Licht. Doubl. p. 72.

Tachydromus temminckii, Swains. Zool. Illustr. pl. 106; West. Afr. ii. p. 230, pl. 24 ; Reichb. f. 2119-20 ; Hartl. West Afr. p. 210; Wagl. Syst. Av. sp. 3; Schleg. Mus. P. B. livr. 7. Curs. p. 13.

Hab. in Africa occident.

4. Cursorius coromandelicus, Gm.

C. asiaticus, Lath.

C. frenatus, Illig.

Tachydromus orientalis, Sw. An. Menag. p. 339 ; Sykes, Catal.

p. 206 ; Jerdon, Birds of Ind. iii. p. 626.

C. coromandelicus, Adams, Proc. Zool. Soc. 1858, p. 504 ; Irby, Ibis, 1861, p. 237 ; Schleg. l. c. p. 13.

$\mathrm{Hab}$. in India contin.

b. Pedibus et rostro brevibus, debilibus; plumis notæi pallide limbatis; fasciis duabus pectoralibus nigris.

5. Cursorius bicinctus, Temm. Man. d'Ornith. ii. p. 514; Gurn. Proc. Zool. Soc. 1864, p. 8; Schleg. l.c.

C. africanus, Temm. Cat. Syst. 1807, p. 175; Jard. \& Selb. Illust. pl. 48.

T. collaris, Vieill.

Charadrius grallator, Leadb. Linn. Trans.

Rhinoptilus bicinctus, Strickl.

Hab. in Africa merid. (Damara, Anderss.).

6. Cursorius bisignatus, Hartl. P. Z. S. 1865, p. 87. (Pl VI.)

Hab. Benguela (Monteiro).

Obs. Rostrum minimum, gracillimum. 
c. Rostro altiore, crassiore; pedibus valde elongatis ; fascia pectorali nigra. (Rhinoptilus.)

7. Cursorius Chalcopterus, Temm. Pl. Col. p. 298; Strickl. P. Z. S. 1850, p. 220 ; Hartl. West Afr.p. 212 ; Heugl. Syst. Uebers. p. 54 ; Gurney, Ibis, 1861, p. 134.

Tachydromus chalcopterus, Sw. West. Afr. ii. p. 220 ; Wagl. Syst. Av. sp. 4.

Rhinoptilus chalcopterus, Sw.

Chalcopterus temminckii, Reichb. Handb. iii. p. 30. f. 2134-35.

Cursorius superciliaris, Heugl. Cab. Journ. 1865, p. 98.

$\mathrm{Hab}$. in Africa merid., occid. et orient.

Note.-Having compared the original specimen of $C$. superciliaris, Heugl., with an authentic example of $C$. chalcopterus from Damaraland, I must declare both to be of the same species.

8. Cursorius bitorquatus, Jerdon, Birds of Ind. iii. p. 628 ; Blyth, Journ. As. Soc. of Beng. xvii. p. 254.

Hab. " Eastern Ghats of Nellore, and Cuddapah."

\section{Cursorius cinctus.}

Hemerodromus cinctus, Heuglin, Ibis, 1864, p. 31, pl. 2.

Hab. Nil. alb. super.

The young of an undescribed (?) species-" certainly of the same form as Rhinoptilus bitorquatus." "It appears to be the young of one of the other African species."-Blyth, App. to Jerdon, B. of Ind. iii. p. 629.

The two last species have not been examined by me.

6. A Revision of the Genera of Pteropine Bats (Pteropida), and the Descriptions of some apparently Undescribed Species. By Dr.John Edward Gray, F.R.S., V.P.Z.S., F.L.S., \&c.

Some years ago I studied the Bats with care, and described some new genera and species, and commenced a monograph of them, of which my papers were to be only the forerunners. My friend $\mathrm{Mr}$. Robert Tomes took up the study, and seemed inclined to devote considerable time to it; so I retired from the position which he so well occupied, and placed the collection of Bats in the Museum entirely at his disposal, hoping some day that he would prepare a catalogue of them; and he has produced some excellent papers on isolated genera and geographic groups. $\mathrm{He}$ is now so occupied with other business that he has not lately been able to give any attention to the subject.

I have been working at other groups of Mammalia, and at length, in the course of my duties, the Bats must be catalogued, and therefore I have, as I may say, been forced to restudy the subject, revise 
my catalogue prepared more than twelve years ago, adding the descriptions of the new species which have been received during that period. I am aware that the best that can be done can only be an essay, leaving much to be corrected and modified.

Since I formerly worked on this group, a number of new species have been described; and M. Gervais, M. de Saussure, and Dr. Peters have published excellent essays, describing the external form, the skulls, dentition, and sometimes the skeletons of different species.

I have great advantages for this undertaking. I have a very large collection under my care, perhaps the largest yet formed in Europe, containing many of the specimens on which species have been founded by different English and foreign authors, those species having been described from the specimens then in the British $\mathrm{Mu}$ seum, or since received from the different European museums.

I can lay the whole series of the specimens of each genus or group out before me and examine and compare them in detail, and repeat the operation as often as I desire. I believe that no such examination of a large collection has been made since M. Geoffroy undertook his series of monographs of different families of Mammalia in the Paris Museum, shortly after Napoleon's accession; and I have the advantage of having a collection much more numerous; indeed, judging by the estimate of the Primates given in his 'Catalogue of Primates,' it must be twice or nearly three times as numerous in specimens as the Museum in Paris.

I have made great progress in this catalogue, some specimens of which have already been laid before the Society ; and the part containing the Primates is now in the press, and I hope it will appear in the course of this spring. I am aware that some zoologists will complain that the characters are too short ; but short as they are, they are the result of much study and analysis. They are the characters that appear to me best suited to distinguish each species from its allies, after a careful examination of a long suite of specimens of each species placed side by side, and with its allies.

It is a labour of love, and I hope to complete the examination and description of the species of the class ; but at my age I have many hindrances. I am fortunately greatly assisted in my study by my excellent helper, Mr. Edward Gerrard, who has a very extensive knowledge of the living and preserved specimens and their osteology ; and his modesty is only equalled by his knowledge.

The examination of the species of the Pteropida has led me to propose the following distribution of the genera, which may be thus characterized :-

\section{Teeth 34 ; true grinders $3 / 3$; hinder small; false grinders $2 / 3$ or $2 / 2$; front small, and often deciduous.}

1. Cutting-teeth $4 / 4$; lower in a reyular series. Tail none. Gland of the penis bony. Pteropina.

1. Pteropus. Wings from the sides of the hairy back. P.medius. 
2. Eunycteris. Wings from the vertebral line; the part of the wing over the back becoming bald. E. phaiops.

2. Cutting-teeth 4/4; lower in a regular series. Tail-end free. Gland of penis soft. Macroglossina.

* Head very long and slender; cutting-teeth in an arched series; grinders compressed, narrow.

3. Notopteris. Wings from the vertebral line; part over the back bald. Head very long and slender. False grinders 1/3. Tail elongate, free. $N$. macdonaldii.

4. Macroglossus. Wings from the sides of the hairy back. Head very long and slender. Tail very short. False grinders 2/3. M. minimus.

** Head moderate; cutting-teeth in a transverse series; grinders thick.

5. Xantharpyia. Wings from sides of the hairy back. Head elongate, tapering. Fur short, adpressed. $X$. straminea.

6. Eleutherura. Wings from sides of the hairy back. Head short, broad. Fur dense, spreading. $E$. marginata.

3. Cutting-teeth $2 / 2$; lower crowded before the base of the canines. Tail-end free. Index finger not clawed. Cephalotina.

7. Сернацотеs. Tail short. Upper cutting-teeth broad; lower truncate. C. peronii* ${ }^{*}$.

II. Teeth 28 ; true grinders $2 / 2,2 / 2$; false grinders $2 / 3$, front minute, often deciduous. Wings from sides of the hairy back. Penis-gland fleshy.

4. Cutting-teeth $2 / 2$ or $2 / 0$, crowded between the canines. Head short, broad. Nostrils tubular, diverging. Harpyiana.

8. Harpyia. Tail short, end free. False grinders 1/1. H. pallasii.

5. Cutting-teeth $4 / 4$; lower in a regular series; false grinders $1 / 1$. Head short, broad; nostrils rather prominent. Glands on shoulder with hair like back. Cynopterina.

9. Cynopterus. Tail short, end free. C. brevicaudata.

10. Megera. Tail none. M. ecaudata.

* The accidentally placing of a label, that was intended for a bottle containing Pteropus amplexicaudatus, on a bottle containing Cephalotes has caused some confusion; thus Cephalotes peronii appears under the name of Xantharpyia amplexicaudata in the 'Voyage of the Sulphur,' and its teeth are described under the name of Pteropus amplexicaudatus in the observations on Notopteris (Proc. Zool. Soc. 1859, p. 36). 
6. Cutting-teeth $4 / 4$; lower in a regular series. Head elongated, swollen in front. Glands on shoulder with a tuft of white hairs. Epomophorina.

11. Eроморs. Face moderate, rounded in front; nose and chin simple, hairy. Skull ovate; face much shorter than the brain-case; upper cutting-teeth separate, spaced. $E$. franqueti.

12. Ероморновus. Face very long, rounded in front; nose and chin simple, hairy. Skull elongate; face as long as brain-case ; upper cutting-teeth close together. $E$. whitei.

13. Hypsignathus. Face very long, swollen and truncated in front; nose and chin with a fleshy disk, with raised edges. $H$. monstrosus.

The Pteropida are spread over the warmer parts of Africa and Asia, and are found in many of the smaller islands of the Indian and Pacific Oceans.

There is a general similarity in the colouring of the majority of the species; specimens found in the same locality or island often vary considerably from one another, even when the examination of the skull and teeth show that they are of the same species. On the other hand, specimens from different localities often resemble one another so much in their external colouring that it is difficult to distinguish them in any description that can be made; but when the skulls and teeth are examined they prove to be very different species. Under these circumstances the locality of the specimens is an important element in determining the species.

\section{Pteropus wallacei, sp. nov.}

Fur very soft, reddish grey brown; hair of the back black, of the belly ashy white with reddish tips; nape and sides of the shoulders grey ; spot on cheek, at angle of mouth, a broad band along the upper lip, a streak upon the centre of the nose (each of them edged with darker brown), the back of the chin, and a lanceolate spot over each eye pure white; the hair on the dorsal surface of the upper arm greyish white. Ears elongate, bald, with two impressed longitudinal grooves.

Hab. Celebes: Macassar (Mr. Wallace, 1857).

This beautiful species was brought to England by Mr. Wallace, but appears to have been overlooked; for Mr. Edward Gerrard, Jun., purchased it at Stevens's sale-room, included in a considerable lot of skins of birds and other animals of little value.

The specimen described is very young (the epiphyses of the bones are all separate), and it doubtless grows to a larger size; but this does not in the least invalidate the distinctness of the species.

There are the young of many species of Pteropine Bats in the British Museum, sometimes with their mothers ; but in every case the young is coloured like the parent, only the colours are not so decidedly marked. This would lead one to believe that the adult

Proc. Zool. Soc.-1866, No. V. 
of this species, if that were possible, would have the colours also more intensified, instead of less so.

I have great pleasure in naming it after Mr. Wallace, who has enriched our Museum with so many new and beautiful species. It is most like Pteropus personatus, but very distinct, and about onethird less in size,

The only other species that has the face ornamented is $P$. personatus; but that has only brown lines on the side of the face and round the eyes. It, like this, is a small species in the genus.

As $P$. personatus has not yet been figured, I have given figures of the heads of the two species for comparison,

Fig. 1.

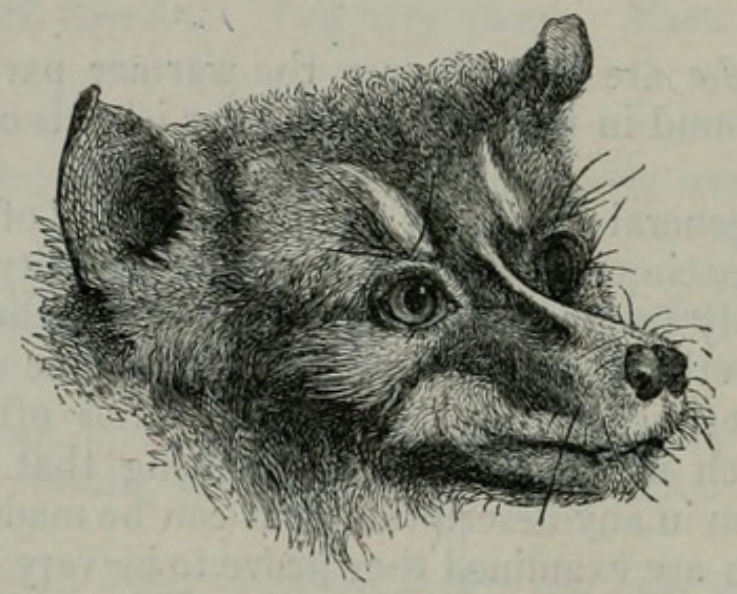

Pteropus wallacei.

Fig. 2 .

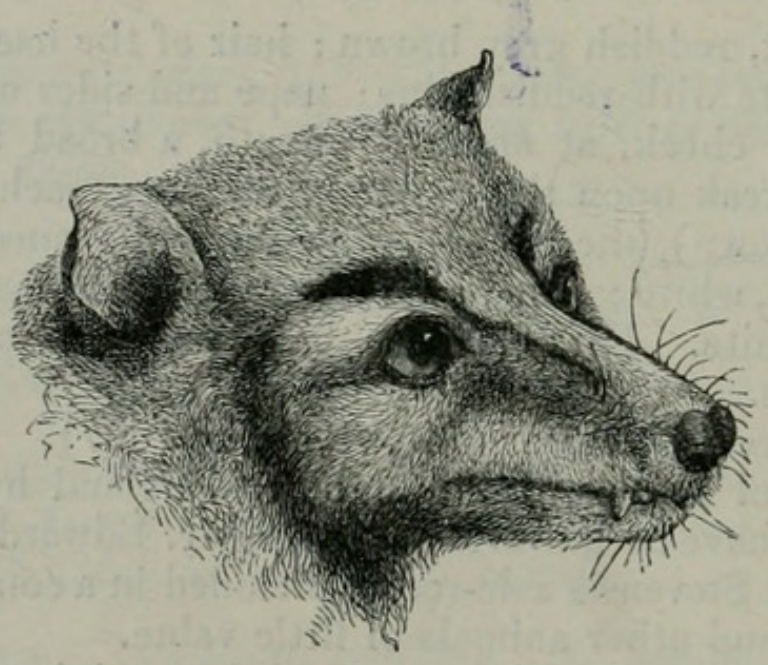

Pteropus personatus.

Pteropus livingstonit, sp. nov.

Deep black; the under surface and the rump with interspersed white hairs, most abundant on the latter part; a small round tuft of bright yellow hair on the upper part of each shoulder.

$\mathrm{Hab}$. Island of Johanna, Comoro group (Dr. Livingstone). 
(.) 


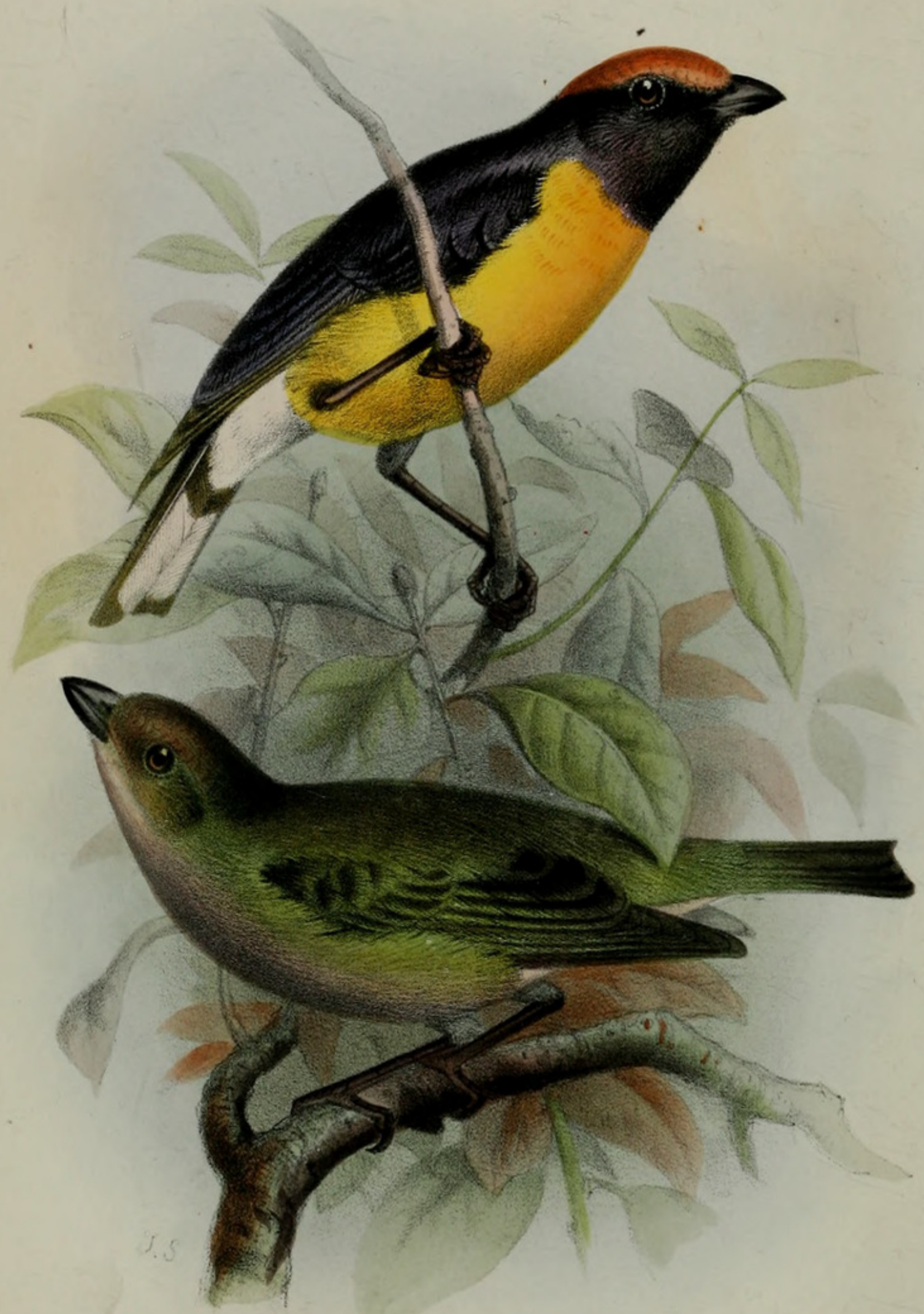




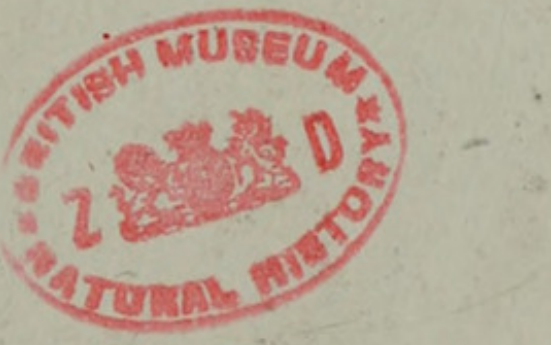




\section{$2 \mathrm{BHL}$ Biodiversity Heritage Library}

Gray, John Edward. 1866. "January 23, 1866." Proceedings of the Zoological Society of London 1866, 34-79.

https://doi.org/10.1111/j.1469-7998.1866.tb00415.x.

View This Item Online: https://www.biodiversitylibrary.org/item/90954

DOI: https://doi.org/10.1111/j.1469-7998.1866.tb00415.x

Permalink: https://www.biodiversitylibrary.org/partpdf/73867.

\section{Holding Institution}

Natural History Museum Library, London

\section{Sponsored by}

Natural History Museum Library, London

\section{Copyright \& Reuse}

Copyright Status: Public domain. The BHL considers that this work is no longer under copyright protection.

This document was created from content at the Biodiversity Heritage Library, the world's largest open access digital library for biodiversity literature and archives. Visit BHL at https://www.biodiversitylibrary.org. 